\title{
Do tree species affect decadal changes in soil organic carbon and total nitrogen stocks in Danish common garden experiments?
}

\author{
Christina Steffens $^{1}$ ( ) | Christian Beer ${ }^{1}$ | Stephanie Schelfhout $^{2}$ | \\ An De Schrijver $^{2,4}$ | Eva-Maria Pfeiffer ${ }^{1}$ | Lars Vesterdal ${ }^{3}$
}

${ }^{1}$ Institute of Soil Science, Center for Earth System Research and Sustainability (CEN), Universität Hamburg, Hamburg, Germany

${ }^{2}$ Department of Environment, Forest and Nature Lab, Ghent University, Ghent, Belgium

${ }^{3}$ Department of Geosciences and Natural Resource Management, Section for Forest, Nature and Biomass, University of Copenhagen, Copenhagen, Denmark

${ }^{4}$ Research Centre AgroFoodNature, HOGENT Univerity of Applied Sciences and Arts Ghent, Ghent, Belgium

\section{Correspondence}

Christina Steffens, Institute of Soil

Science, Center for Earth System Research and Sustainability (CEN), Universität

Hamburg, Hamburg.

Email: christina.steffens@uni-hamburg.de

\section{Funding information}

Deutsche Forschungsgemeinschaff (DFG), Grant/Award Number: 10.13039/

501100001659

\begin{abstract}
Temperate forest soils are often considered as an important sink for atmospheric carbon (C), thereby buffering anthropogenic $\mathrm{CO}_{2}$ emissions. However, the effect of tree species composition on the magnitude of this sink is unclear. We resampled a tree species common garden experiment (six sites) a decade after initial sampling to evaluate whether forest floor $(\mathrm{FF})$ and topsoil organic carbon $\left(\mathrm{C}_{\text {org }}\right)$ and total nitrogen $\left(\mathrm{N}_{\mathrm{t}}\right)$ stocks changed in dependence of tree species (Norway spruce-Picea abies L., European beech-Fagus sylvatica L., pedunculate oak-Quercus robur L., sycamore maple-Acer pseudoplatanus L., European ash-Fraxinus excelsior L. and small-leaved lime-Tilia cordata L.). Two groups of species were identified in terms of $\mathrm{C}_{\text {org }}$ and $\mathrm{N}_{\mathrm{t}}$ distribution: (1) Spruce with high $\mathrm{C}_{\text {org }}$ and $\mathrm{N}_{\mathrm{t}}$ stocks in the FF developed as a mor humus layer which tended to have smaller $\mathrm{C}_{\text {org }}$ and $\mathrm{N}_{\mathrm{t}}$ stocks and a wider $\mathrm{C}_{\text {org }}: \mathrm{N}_{\mathrm{t}}$ ratio in the mineral topsoil, and (2) the broadleaved species, of which ash and maple distinguished most clearly from spruce by very low $\mathrm{C}_{\text {org }}$ and $\mathrm{N}_{\mathrm{t}}$ stocks in the FF developed as mull humus layer, had greater $\mathrm{C}_{\text {org }}$ and $\mathrm{N}_{\mathrm{t}}$ stocks, and narrow $\mathrm{C}_{\text {org }}: \mathrm{N}_{\mathrm{t}}$ ratios in the mineral topsoil. Over 11 years, FF $\mathrm{C}_{\text {org }}$ and $\mathrm{N}_{\mathrm{t}}$ stocks increased most under spruce, while small decreases in bulk mineral soil (esp. in $0-15 \mathrm{~cm}$ and $0-30 \mathrm{~cm}$ depth) $\mathrm{C}_{\text {org }}$ and $\mathrm{N}_{\mathrm{t}}$ stocks dominated irrespective of species. Observed decadal changes were associated with site-related and tree species-mediated soil properties in a way that hinted towards short-term accumulation and mineralisation dynamics of easily available organic substances. We found no indication for $\mathrm{C}_{\text {org }}$ stabilisation. However, results indicated increasing $\mathrm{N}_{\mathrm{t}}$ stabilisation with increasing biomass of burrowing earthworms, which were highest under ash, lime and maple and lowest under spruce.
\end{abstract}




\section{Highlights}

- We studied if tree species differences in topsoil $\mathrm{C}_{\text {org }}$ and $\mathrm{N}_{\mathrm{t}}$ stocks substantiate after a decade.

- The study is unique in its repeated soil sampling in a multisite common garden experiment.

- Forest floors increased under spruce, but topsoil stocks decreased irrespective of species.

- Changes were of short-term nature. Nitrogen was most stable under arbuscular mycorrhizal species.

\section{K E Y W O R D S}

accumulation, carbon sequestration, clay, dynamics, earthworms, forest floor, forest topsoil, soil nitrogen, soil organic carbon, temperate tree species

\section{1 | INTRODUCTION}

Forest soils contain $\sim 60 \%$ of the total organic carbon $\left(\mathrm{C}_{\mathrm{org}}\right)$ stored in temperate forests, and forests are often considered as sinks for atmospheric $\mathrm{C}$ (Goodale et al., 2002; Lal, 2005; Pan et al., 2011). The nitrogen (N) cycle is closely coupled with the C cycle (Schulze, 2000), for example, a greater $\mathrm{N}$ supply might lead to an increased biomass production and thus increased litter input to the forest floor (FF). As $\mathrm{N}$ is often the limiting nutrient in forest ecosystems, and $\mathrm{C}_{\text {org }}: \mathrm{N}_{t}$ ratios in organic matter are relatively stable, soil $\mathrm{C}_{\text {org }}$ sequestration rates are directly linked to, for example, $\mathrm{N}$ deposition (Gundersen et al., 2006). The understanding of how tree species selection might increase this $\mathrm{C}$ and $\mathrm{N}$ sink function is of high relevance, but not yet fully understood (Mayer et al., 2020).

Tree species effects on $\mathrm{FF} \mathrm{C}_{\text {org }}$ and $\mathrm{N}_{\mathrm{t}}$ stocks have been found in several studies and appeared to be remarkably consistent. They decreased from conifers over beech and/or oak-dominated forests to other broadleaved forests (Fleck et al., 2019; Peng et al., 2020; Vesterdal et al., 2013). In the mineral topsoil, this ranking often appeared to be vice versa (Fleck et al., 2019; Peng et al., 2020; Rodeghiero et al., 2018; Vesterdal et al., 2013), but in the case of topsoil $\mathrm{C}_{\text {org }}$ stocks, species effects were only found in $\sim 60 \%$ of the studies and seem to be context-dependent (Boca et al., 2014; Langenbruch et al., 2012; Mayer et al., 2020; Peng et al., 2020; Vesterdal et al., 2013). It remains unclear which biochemical and climatic parameters favour species effects on topsoil $\mathrm{C}_{\text {org }}$ stocks and how these stocks change with time (Mayer et al., 2020).

Changes in $\mathrm{C}_{\text {org }}$ and $\mathrm{N}_{\mathrm{t}}$ stocks can be measured either directly via repeated sampling (Achilles et al., 2021; Grüneberg et al., 2014) or indirectly, that is, by mass balances quantifying input and output fluxes (Angst, Mueller, Eissenstat, et al., 2019; Vesterdal et al., 2012). The latter provide valuable insights into the controlling processes, but they are very laborious and seldom include all input and output parameters with sufficient precision. Direct measurement of $\mathrm{C}_{\text {org }}$ and $\mathrm{N}_{\mathrm{t}}$ stock changes in forest soils is challenging as they may only be detectable after $\sim 10$ years depending on the magnitude of the expected changes (Lawrence et al., 2013, 2016; Schrumpf et al., 2011). Monitoring forest soil $\mathrm{C}_{\text {org }}$ stock changes via repeated sampling have been reported at larger spatial scales from national forest soil inventories (Grüneberg et al., 2014; Jonard et al., 2017) and after land-use change such as afforestation (Li et al., 2015) and reforestation (Shao et al., 2019). These soil monitorings show a strong spatial range from soil $\mathrm{C}_{\text {org }}$ and $\mathrm{N}_{\mathrm{t}}$ losses to uptakes. Very recently, Achilles et al. (2021) found decadal losses of FF $\mathrm{C}_{\text {org }}$ under beech-dominated, but not under coniferous stands in Central Germany, while topsoil $\mathrm{C}_{\text {org }}$ and $\mathrm{N}_{\mathrm{t}}$ concentrations remained unchanged in beech-dominated and coniferous stands. We are not aware of any study that repeatedly measured soil $\mathrm{C}_{\text {org }}$ and $\mathrm{N}_{\mathrm{t}}$ stocks in common garden experiments to estimate their changes on a species level.

Changes in forest soil $\mathrm{C}_{\text {org }}$ and $\mathrm{N}_{\mathrm{t}}$ stocks could either be of short-term nature by interannual variation in accumulation and mineralisation dynamics, for example, due to temperature and moisture differences, or of longerterm nature through stabilisation processes (Jandl et al., 2007). Recalcitrance is considered as a factor for short-term stabilisation, while spatial inaccessibility, mineral associations and complexation with metal ions were identified as factors relevant for long-term stabilisation (Kögel-Knabner et al., 2008). Cotrufo et al. (2013) suggested that tree species with nutrient-rich litter and fast microbially mediated decomposition are 
better suited for long-term sequestration of $\mathrm{C}_{\text {org }}$ stocks than species with recalcitrant litter and high $\mathrm{FF} \mathrm{C}_{\text {org }}$ stocks.

The common garden experimental sites in Denmark have been intensively studied with respect to $\mathrm{C}_{\text {org }}$ and $\mathrm{N}_{\mathrm{t}}$ stocks and relevant driving parameters under six tree species (European beech [Fagus sylvatica L.], pedunculate oak [Quercus robur L.], sycamore maple [Acer pseudoplatanus L.], small-leaved lime [Tilia cordata L.], European ash [Fraxinus excelsior L.] and Norway spruce [Picea abies L.]): (1) FF $\mathrm{C}_{\text {org }}$ and $\mathrm{N}_{\mathrm{t}}$ stocks decreased in the order spruce $>$ beech, oak $>$ maple, lime, ash (Vesterdal et al., 2008) and (2) topsoil $\mathrm{C}_{\text {org }}$ and $\mathrm{N}_{\mathrm{t}}$ stocks in 15-30 cm depth were highest under ash and lime and lowest under spruce. (3) The $\mathrm{C}_{\mathrm{org}}: \mathrm{N}_{\mathrm{t}}$ ratio down to $15 \mathrm{~cm}$ soil depth was highest under spruce and lowest under maple and ash. (4) Burrowing earthworms contributing to bioturbation, were most abundant under ash, maple and lime and almost absent under spruce (Schelfhout et al., 2017). (5) Soils under species associated with ectomycorrhiza (ECM), that is, beech, oak, lime and spruce (Harley \& Harley, 1987), showed greater fungal and bacterial biomass and fungal growth, while soils under species associated with arbuscular mycorrhiza (AM), that is, maple and ash, showed greater bacterial growth (Hedenec et al., 2020). The question remains whether the reported differences in $\mathrm{C}_{\text {org }}$ and $\mathrm{N}_{\mathrm{t}}$ stocks will substantiate with time and whether the wide range in tree species litter quality, mycorrhizal association and associated soil biota may explain such temporal changes in soil $\mathrm{C}_{\text {org }}$ and $\mathrm{N}_{\mathrm{t}}$ stocks.

In this study, we evaluated decadal FF and mineral topsoil $\mathrm{C}_{\text {org }}$ and $\mathrm{N}_{\mathrm{t}}$ stock changes from repeated soil sampling under the respective six tree species at six common garden experimental sites located across Denmark. We aimed to evaluate consistent tree species effects across multiple sites with a wide range in soil texture. We expected small changes in $\mathrm{C}_{\text {org }}$ and $\mathrm{N}_{\mathrm{t}}$ stocks after one decade, that is, in these forest stands from $\sim 30$ to $\sim 40$ years of age, and we expected that tree species-related differences widened during a decade. Specifically, we expected that the accumulation of $\mathrm{C}_{\mathrm{org}}$ and $\mathrm{N}_{\mathrm{t}}$ would be more pronounced in the topsoil under AM species and tree species with high-quality litter and a high abundance of bioturbating earthworms, while in ECM species and tree species with lower quality litter and low abundance or absence of earthworms, greater amounts of $\mathrm{C}_{\text {org }}$ and $\mathrm{N}_{\mathrm{t}}$ would accumulate in the FF. We hypothesised that topsoil accumulation of $\mathrm{C}_{\text {org }}$ and $\mathrm{N}_{t}$ would be highest under ash and maple, followed by lime, intermediate under beech and oak, and lowest under spruce, while we expected highest $\mathrm{C}_{\text {org }}$ and $\mathrm{N}_{\mathrm{t}}$ accumulation in the FF under spruce.

\section{MATERIALS AND METHODS}

\subsection{Common garden experiment}

This study was conducted in a common garden experiment replicated at six sites located across Denmark that varied in climatic and soil conditions as well as the previous landuse (Table 1). Each site contained monoculture stands of six tree species (European beech, pedunculate oak, sycamore maple, small-leaved lime, European ash and Norway spruce) that were planted in adjacent blocks of each ca. 0.25 ha in 1973; except for Kragelund, where stands were smaller and trees were planted in 1961. The studied tree species differed in litter chemistry, biomass production, mycorrhizal association and earthworm communities (Table 2). The sites were thinned approximately every 4 years. The last thinning was conducted in 2015. See Vesterdal et al. (2008) for a full description of the study design.

\section{2 | FF and mineral soil sampling and sample preparation}

We resampled the FF and mineral soil in 2015/2016 in the same season as 11 years before in the initial sampling campaign (Vesterdal et al., 2008). The FF of each stand was resampled in the second week of September 2016, that is, directly before the start of the dormant season, by collecting 10 samples evenly distributed across the stand with a cylinder (diameter: $20 \mathrm{~cm}$ ). The 10 samples of each species stand were pooled to one composite sample. FF humus forms were characterised according to Zanella et al. (2011).

The mineral topsoil was resampled between November 2015 and March 2016 by taking 15 soil cores evenly distributed across each species stand with an auger designed for undisturbed soil sampling (diameter: $5 \mathrm{~cm}$ ) down to $30 \mathrm{~cm}$ soil depth. The soil cores were carefully divided into three depth increments: $0-5 \mathrm{~cm}, 5-15 \mathrm{~cm}$ and $15-30 \mathrm{~cm}$. Subsequently, the 15 samples of each depth increment were pooled to one sample per species stand. By this method, we aimed at minimising effects related to small-scale spatial variability in concentrations of $\mathrm{C}_{\text {org }}$ and $\mathrm{N}_{\mathrm{t}}$ and at deriving a value quite close to the true plot mean.

The FF samples were air-dried at room temperature until constant weight was achieved; grasses, herbs and mosses were removed. Subsequently, the FF samples were divided into foliar (i.e., leaf litter material) and nonfoliar (i.e., fruits, twigs, branches) compartments and weighed. After well mixing of the sample, part of the foliar forest floor (FFF) was ground-depending on the volume of the sample either with the disc vibration mill (Scheibenschwingmühle-TS, Siebtechnik, Mülheim an 


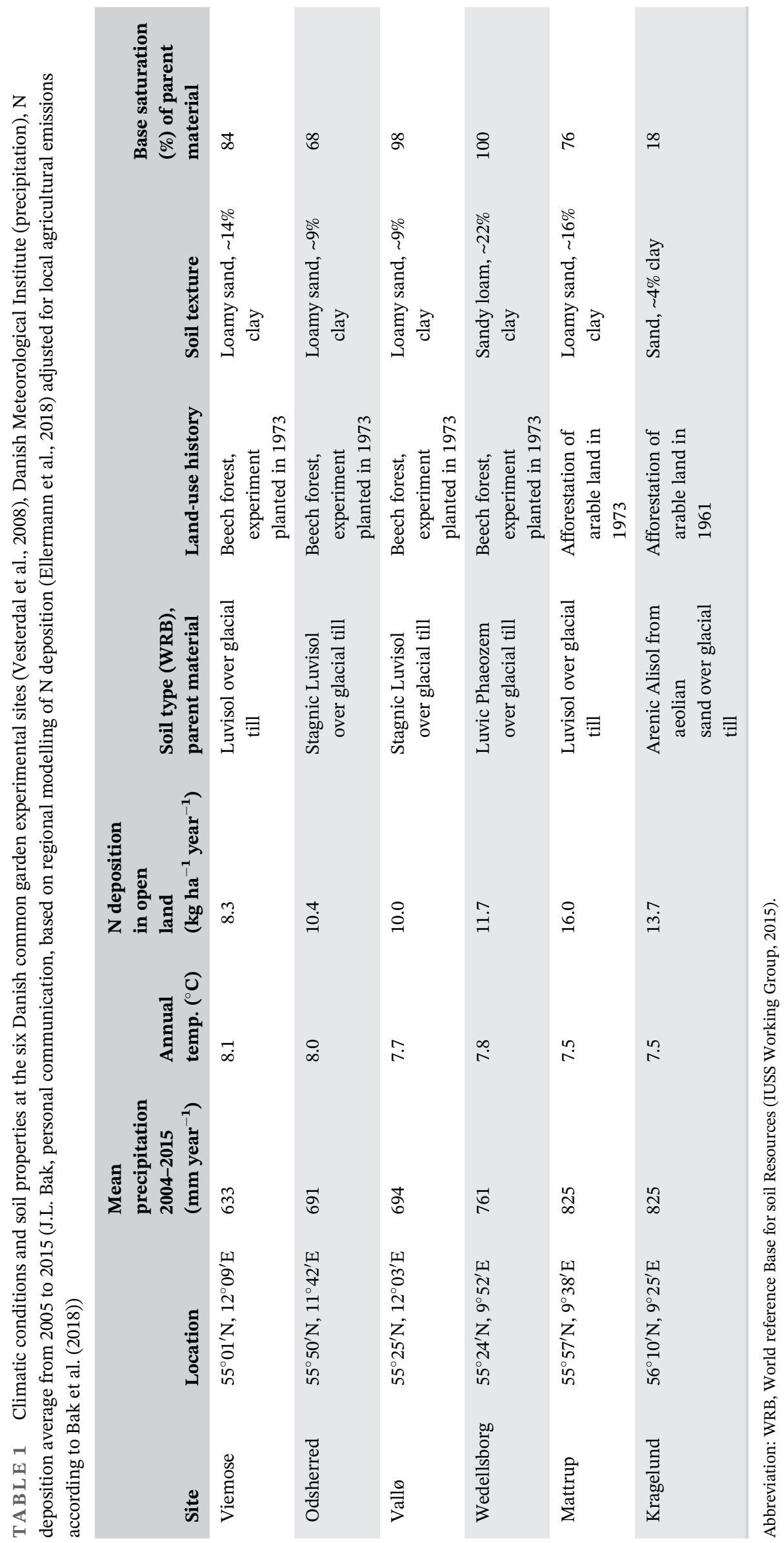




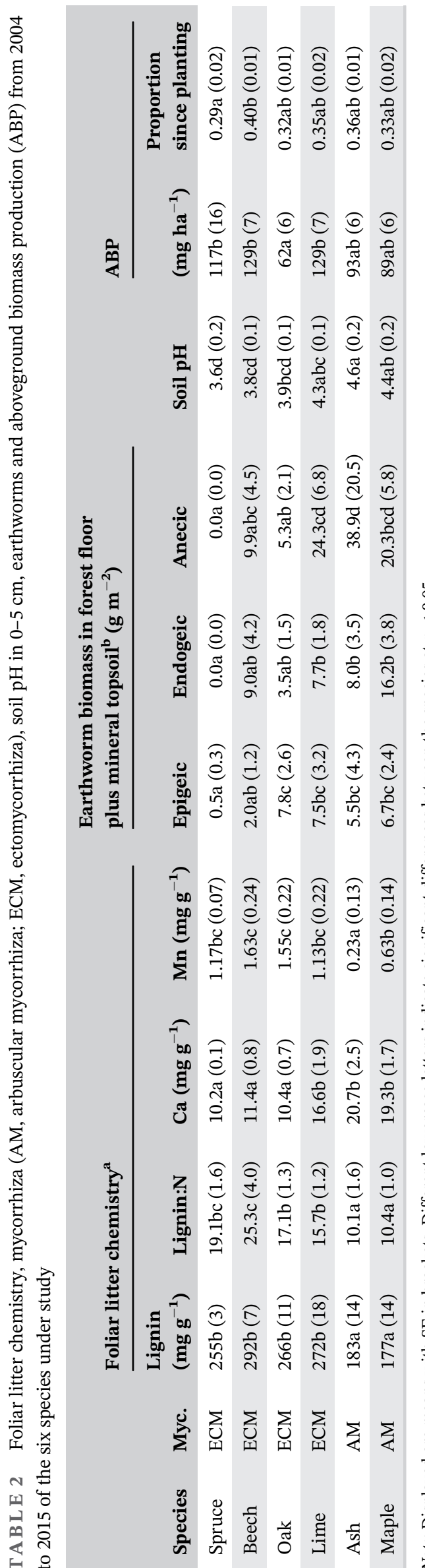

der Ruhr, Germany) or with the mixer mill (MM 400, Retsch, Haan, Germany)-to fine material. The nonfoliar part of the FF was very heterogeneous, and, hence, ground completely.

The fresh mineral topsoil samples were weighed and subsequently sieved to $2 \mathrm{~mm}$. A subset was used for deriving the moisture content and the remaining part was air-dried at room temperature until constant weight. Coarse material (gravel and stones) was weighed. Bulk density of the fine mineral soil $(<2 \mathrm{~mm}$ ) of the individual depth increments was derived similarly to the method in Vesterdal et al. (2008). A subsample of each sieved soil sample was ground to fine material in the disc vibration mill (Scheibenschwingmühle-TS, Siebtechnik, Mülheim an der Ruhr, Germany).

\section{3 | Chemical analyses}

Prior to measurements, the ground $\mathrm{FF}$ and mineral soil samples were dried at $105^{\circ} \mathrm{C}$ for $24 \mathrm{~h}$. To derive the $\mathrm{C}_{\text {org }}$ and $\mathrm{N}_{\mathrm{t}}$ concentrations, all samples were analysed by dry combustion, however, the instrument used differed between the 2004/2005 samples (a Leco CSN 2000 Analyzer, Michigan, USA) and the 2015/2016 samples (an Elementar VarioMax analyser, Hanau, Germany). To account for instrumentrelated differences, a subset of the 2004/2005 samples were re-analysed after drying at $105^{\circ} \mathrm{C}$ for $24 \mathrm{~h}$ with the VarioMax analyser. Two tests were conducted to account for instrument comparability: (1) Paired $t$-tests with original (Leco) and remeasured (VarioMax) values. (2) Regression: The deviation of the remeasured values (VarioMax) from the originally measured (Leco) values was calculated and these deviations were plotted on the $y$-axis against the values from original measurements at the Leco on the $x$-axis. The $\mathrm{C}_{\text {org }}$ concentrations were comparable ( $t$-test: $p>0.9$; regression: $p=0.305)$ between the two instruments $\left(\mathrm{C}_{2015 / 16}=1.0415 * \mathrm{C}_{2004 / 05}-0.0777, R^{2}=0.98\right)$, but $\mathrm{N}_{\mathrm{t}}$ concentrations needed corrections ( $t$-test: $p<0.1$, regression: $p<0.1$ ) by the observed linear relationship $\left(\mathrm{N}_{2015 / 16}=1.1112 * \mathrm{~N}_{2004 / 05}+0.0137, R^{2}=0.98\right)$. Analogous to Vesterdal et al. (2008), we assumed all measured $\mathrm{C}$ to be organic and that there was no $\mathrm{CaCO}_{3}$ in the samples, because $\mathrm{pH}$ measured in $\mathrm{CaCl}_{2}$ (not shown) was below 5.5 .

\section{4 | Calculation of $\mathrm{C}_{\text {org }}$ and $\mathrm{N}_{\mathrm{t}}$ stocks and decadal changes}

FF $\mathrm{C}_{\text {org }}$ and $\mathrm{N}_{\mathrm{t}}$ stocks were calculated by multiplying the sampled mass with the area of the sampling frame. Soil densities decreased irrespective of site and species 


\begin{tabular}{|lccc|}
\hline Soil layer & & $\mathbf{2 0 0 4 / 2 0 0 5}$ & $\mathbf{2 0 1 5 / 2 0 1 6}$ \\
\hline $0-5 \mathrm{~cm}$ & Soil density $\left(\mathrm{g} \mathrm{cm}^{-3}\right)$ & $0.82(0.03)$ & $0.65(0.02)$ \\
\hline $5-15 \mathrm{~cm}$ & & $1.17(0.02)$ & $1.02(0.02)$ \\
\hline $15-30 \mathrm{~cm}$ & & $1.42(0.02)$ & $1.31(0.04)$ \\
\hline $350 \mathrm{Mg} \mathrm{soil} \mathrm{ha}{ }^{-1}$ & Corresponding soil depth $(\mathrm{cm})$ & $4.4(0.1)$ & $5.6(0.2)$ \\
\hline $1400 \mathrm{Mg} \mathrm{soil} \mathrm{ha}^{-1}$ & & $13.7(0.2)$ & $15.8(0.3)$ \\
\hline $3400 \mathrm{Mg} \mathrm{soil} \mathrm{ha}^{-1}$ & & $27.9(0.3)$ & $31.7(0.8)$ \\
\hline
\end{tabular}

Note: Displayed are means across all sites and species with SE in brackets.
T A B L E 3 Soil density of the depth increments and corresponding lower soil depth (i.e., $0 \mathrm{~cm}$ to corresponding depth) of the equivalent soil masses in 2004 and 2015
(Table 3) from 2004/2005 to 2015/2016, which could be caused either by methodological bias or by true changes in bulk density. As suggested for soil monitoring studies on stock changes (Lee et al., 2009; Wendt \& Hauser, 2013), we calculated equivalent soil masses (ESM) that correspond to the different depth increments by cubic spline via bulk densities of the different soil depth increments. We used the MS Excel template provided for download by Wendt and Hauser (2013). We observed three ESM (Table 3) that corresponded to the mean depth increments $0-5 \mathrm{~cm}, 0$ $15 \mathrm{~cm}$ and $0-30 \mathrm{~cm}$. The topsoil $\mathrm{C}_{\text {org }}$ and $\mathrm{N}_{\mathrm{t}}$ stocks were calculated based on the ESM, but for easier readability we will refer to the mean depth increments within the result and discussion section.

Stock changes were calculated by Equation (1).

$$
\text { Change }_{(\mathrm{dec})}=\left(\mathrm{X}_{2015}-\mathrm{X}_{2004}\right) / 11 \text { year } * 10 \text { years, }
$$

with ' $\mathrm{X}$ ' being the value of the parameter within the certain year. Negative changes indicate a loss in stocks, while positive changes indicate an increase.

We had data obtained at two time points that allowed us to calculate changes on a linear basis. Soil $\mathrm{C}_{\text {org }}$ and $\mathrm{N}_{\mathrm{t}}$ stocks will reach a saturation level at some point ( $\mathrm{Six}$ et al., 2002) and changes cannot necessarily be expected to be linear. Nonetheless, we think that the calculation of linear changes over one decade is quite close to true conditions due to the following two reasons: (1) As land-use change happened 30-40 years ago, the soil $\mathrm{C}$ and $\mathrm{N}$ stocks have most likely not reached steady-state conditions yet (Mayer et al., 2020), that is, the stocks have not yet reached the saturation level. (2) One decade is a very short time scale in respect to soil development time scales. Therefore, we assume that the pattern will not differ much from linear conditions within the decadal time scale.

Absolute changes in $\mathrm{N}_{t}$ stocks were negatively correlated with initial $\mathrm{N}_{\mathrm{t}}$ stocks in all soil masses, and absolute changes in $\mathrm{C}_{\text {org }}$ stocks in $0-15 \mathrm{~cm}$ were negatively correlated with initial $\mathrm{C}_{\text {org }}$ stocks. These correlations might hint towards regression to the mean (RTM; Barnett et al., 2005).
However, as for relative changes (Equation (2)), these correlations were absent, except for $\mathrm{N}_{\mathrm{t}}$ stock changes in 0-30 cm, we propose that RTM had been negligible in this study.

$$
\text { Rel_Change }_{(\mathrm{dec})}=\left(\text { Change }_{(\mathrm{dec})} / \mathrm{X}_{2004}\right) * 100 \%
$$

In 2005, the spruce stands had been damaged by storm and clear-cut at two sites (Kragelund and Wedellsborg). We only considered spruce soil changes since 2004 from those sites where they were still present in 2015 , that is, we included data from four sites for spruce for both years.

\section{5 | Statistical analyses}

To detect possible differences in $\mathrm{C}_{\text {org }}$ and $\mathrm{N}_{\mathrm{t}}$ stocks, $\mathrm{C}_{\text {org }}$ : $\mathrm{N}_{\mathrm{t}}$ ratio as well as their relative decadal changes and vertical distribution between the six tree species and three species types ((1) coniferous species [CF-ECM]: spruce; (2) broadleaved species associated with ectomycorrhiza [BL-ECM]: beech, oak and lime, (3) broadleaved species associated with arbuscular mycorrhiza [BL-AM]: maple and ash) across the sites, we used analysis of variance with site as random factor followed by Tukey's HSD test $(p<0.05)$. In cases, residuals were not (almost) normally distributed (Shapiro-Wilk-test, $p<0.05$ ) and/or variances were not homogeneous (Levene, $p<0.05$ ), data were transformed using the natural logarithm. If no transformation of the data was possible, a Kruskal-Wallis rank sum test followed by pairwise comparison using the Wilkoxon rank sum test was conducted instead (Table S1). These statistical analyses were conducted by R 3.6.0 using the packages 'Ime4' Version 1.1-21 (Bates et al., 2015), 'ImerTest' Version 3.1-1 (Kuznetsova et al., 2017), 'car' Version 3.0-6 (John Fox, 2019), 'multcompView' Version 0.1-8 (Spencer Graves et al., 2019) and 'Ismeans' Version 2.30-0 (Lenth, 2016).

We further conducted automatic multiple linear regression analyses with stepwise forward inclusion of explanatory variables (limited to a maximum of three; 
T A B L E 4 Tree species-mediated and site-mediated variables tested for their explanatory strength in multiple linear regression analyses and examples of the relevant underlying processes and/or correlations with $\mathrm{C}_{\mathrm{org}}$ and $\mathrm{N}_{\mathrm{t}}$ stocks as suggested from the literature

\begin{tabular}{|c|c|c|c|c|}
\hline \multicolumn{3}{|l|}{ Variables } & \multirow{2}{*}{$\begin{array}{l}\text { Mechanism } \\
\text { Organic matter production, } \\
\text { affecting litterfall rate }\end{array}$} & \multirow{2}{*}{$\begin{array}{l}\text { Reference } \\
\text { Hansen et al. (2009) }\end{array}$} \\
\hline Tree species-mediated & Biomass production & $\mathrm{ABP}$ & & \\
\hline & Earthworms & $\begin{array}{l}\text { Biomass of burrowing } \\
\text { earthworms }\end{array}$ & $\begin{array}{l}\text { Bioturbation, stabilisation of } \\
\text { soil carbon in aggregates }\end{array}$ & $\begin{array}{l}\text { Curry \& Schmidt (2007), } \\
\text { Angst, Mueller, Prater, } \\
\text { et al. (2019) }\end{array}$ \\
\hline & & $\begin{array}{l}\text { Biomass of epigeic } \\
\text { earthworms }\end{array}$ & Litter-dwelling species & $\begin{array}{l}\text { Curry \& Schmidt (2007), } \\
\text { Angst, Mueller, Prater, } \\
\text { et al. (2019) }\end{array}$ \\
\hline & Acidity & Soil pH & $\begin{array}{l}\text { Affects microbial biomass and } \\
\text { activity }\end{array}$ & $\begin{array}{l}\text { Angst, Mueller, Eissenstat, } \\
\text { et al. (2019), Hedenec } \\
\text { et al. (2020) }\end{array}$ \\
\hline & & Lignin:N & $\begin{array}{l}\text { Affects litter decomposition } \\
\text { rate }\end{array}$ & Mellilo et al. (1982) \\
\hline & & $\mathrm{Ca}$ & Relevant for earthworms & Hobbie et al. (2006) \\
\hline & & $\mathrm{Mn}$ & $\begin{array}{l}\text { Essential for activity of Mn } \\
\text { peroxidase, a lignin- } \\
\text { degrading enzyme }\end{array}$ & Berg (2000) \\
\hline \multirow[t]{6}{*}{ Site- and soil-mediated } & Climate & MAT & $\begin{array}{l}\text { Affects microbial activity and } \\
\text { turnover of labile organic } \\
\text { matter }\end{array}$ & Jandl et al. (2007) \\
\hline & Soil properties & $\begin{array}{l}\text { Clay content and clay } \\
+ \text { silt content }\end{array}$ & $\begin{array}{l}\text { Adsorption of organic matter } \\
\text { to minerals, C stabilisation }\end{array}$ & $\begin{array}{l}\text { Jandl et al. (2007); Six } \\
\text { et al. (2002) }\end{array}$ \\
\hline & & Base saturation & $\begin{array}{l}\text { Affects microbial biomass and } \\
\text { activity }\end{array}$ & $\begin{array}{l}\text { Angst, Mueller, Eissenstat, } \\
\text { et al. (2019), Hedenec } \\
\text { et al. (2020) }\end{array}$ \\
\hline & & Exchangeable $\mathrm{Ca}^{2+}$ & $\begin{array}{l}\text { Relevant for earthworms; } \\
\text { bridges between mineral } \\
\text { surfaces and organic matter }\end{array}$ & $\begin{array}{l}\text { Hobbie et al. (2007); } \\
\text { Rasmussen et al. (2018) }\end{array}$ \\
\hline & & Exchangeable $\mathrm{Fe}^{3+}$ & Organo-metal complexes & Rasmussen et al. (2018) \\
\hline & & Exchangeable $\mathrm{Al}^{3+}$ & Organo-metal complexes & Rasmussen et al. (2018) \\
\hline
\end{tabular}

Note: ABP: aboveground biomass production (2004-2005); ABP\%: proportion of aboveground biomass production since planting occurring in the period 20042015; biomass of burrowing earthworms: endogeic and anecic species; soil pH measured in 0-5 cm in 2004; foliar litter nutrients measured in 2004 ; mean openfield N deposition from 2004 to 2015; MAT and MAP: mean annual air temperature and precipitation from 2004 to 2015; exchangeable cations in 15-30 cm measured in 2004/2005; clay content and clay plus silt content in 15-30 cm measured in 2015/2016; base saturation of the parent material measured in $2004 / 2005$.

Table 4) for observed differences in decadal changes of $\mathrm{C}_{\text {org }}$ and $\mathrm{N}_{\mathrm{t}}$ stocks as well as $\mathrm{C}_{\text {org }}: \mathrm{N}_{\mathrm{t}}$ ratio by IBM SPSS Statistics Version 27. Prior to multiple regression analyses, all parameters were checked for linearity. If necessary, the parameters had been square-root or ln-transformed (Table S2). 


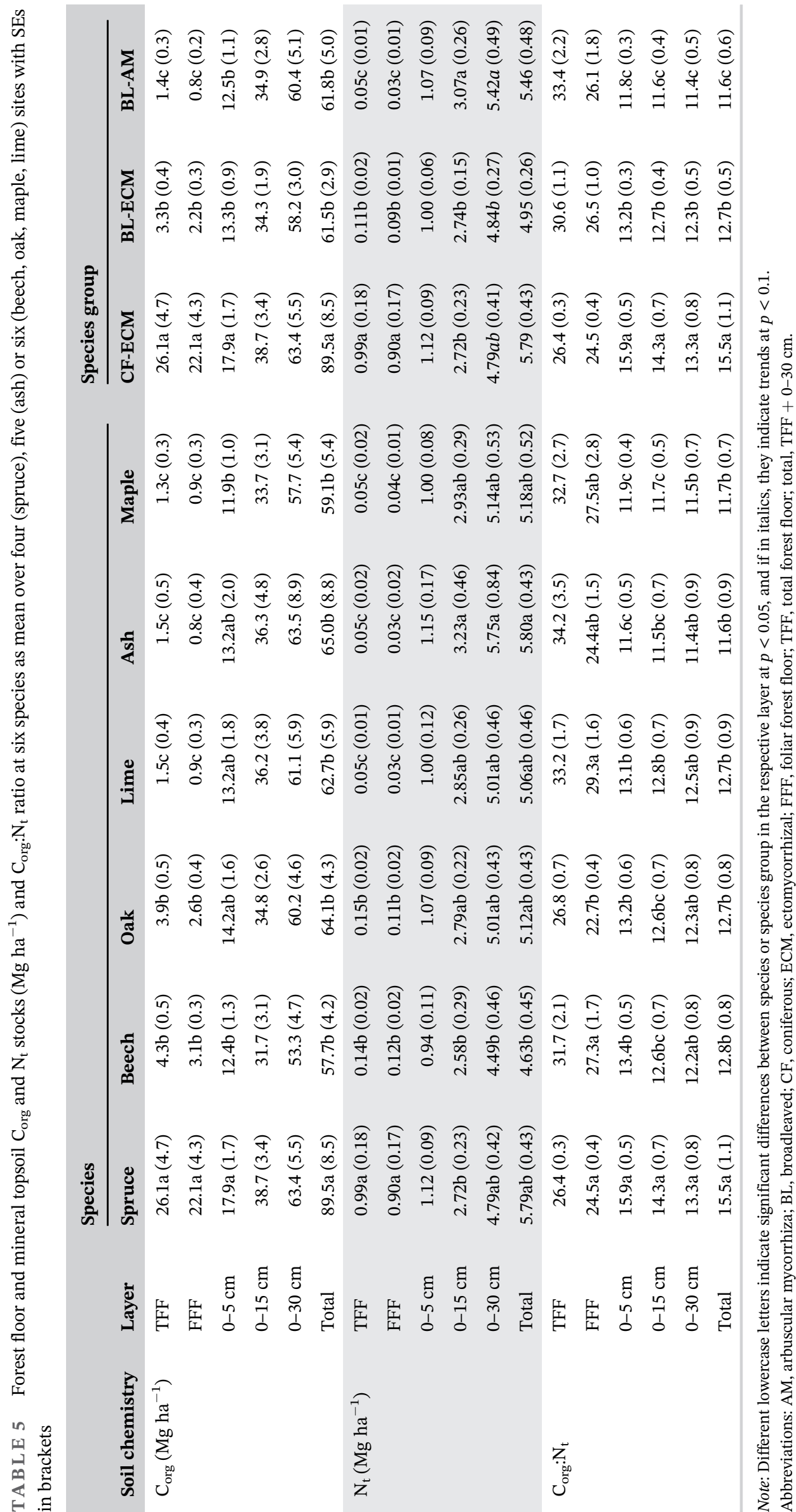


F I G URE 1 Mean relative contributions of the different soil layers to total $\mathrm{C}_{\text {org }}$ (a) and $\mathrm{N}_{\mathrm{t}}$ (b) stock in forest floor plus mineral topsoil $(0-30 \mathrm{~cm})$ in $2015 / 2016$ under six tree species. The error bars correspond to \pm 1

SE. Different lowercase letters indicate significant differences between species for the respective soil layer at $p<0.05$
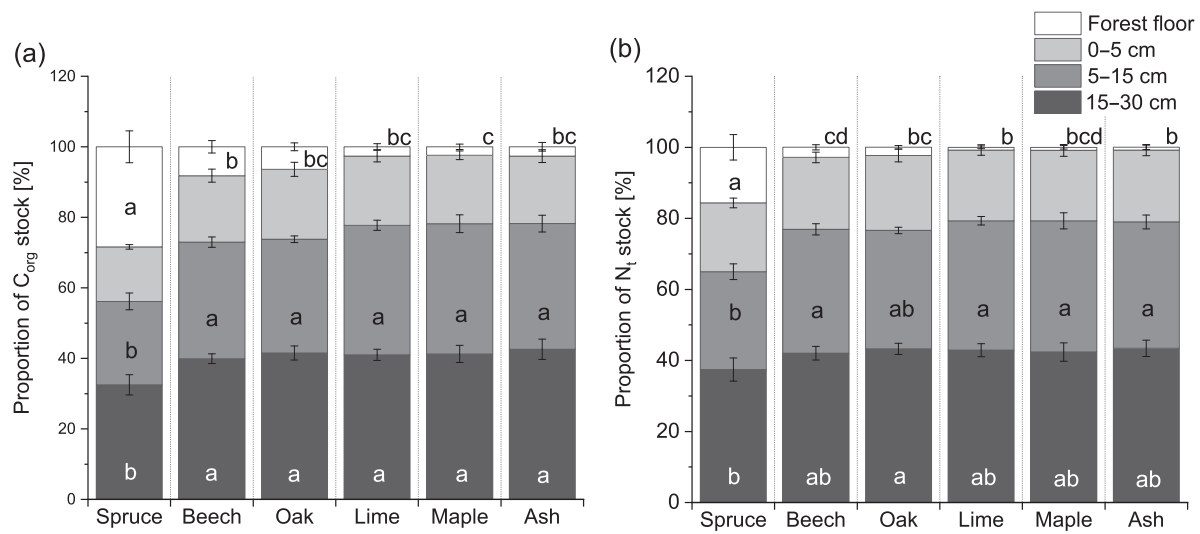

(a)

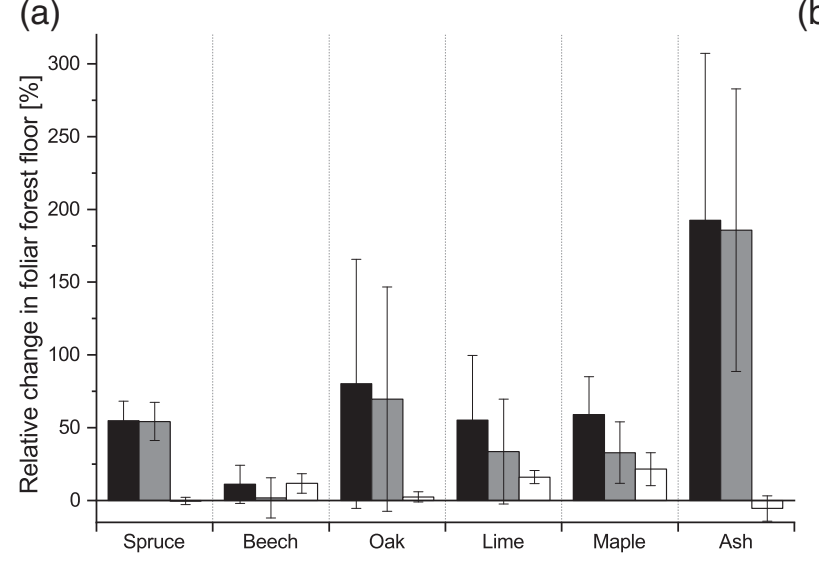

(c)

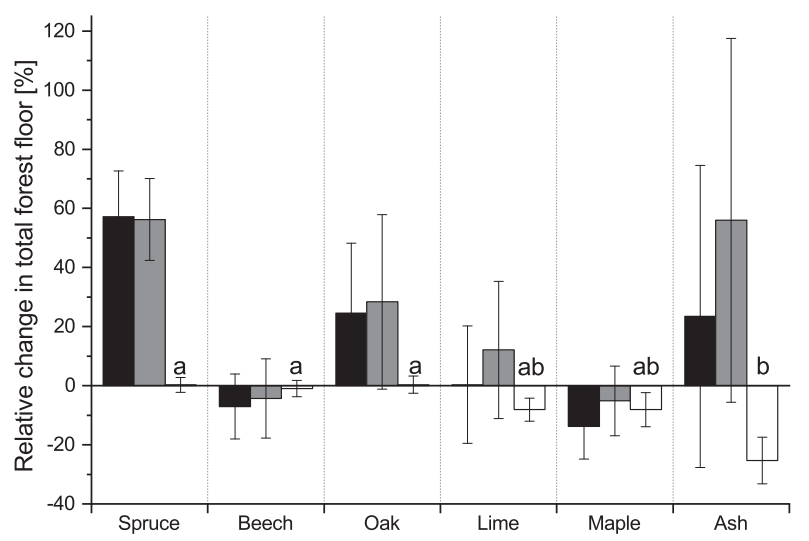

(b)

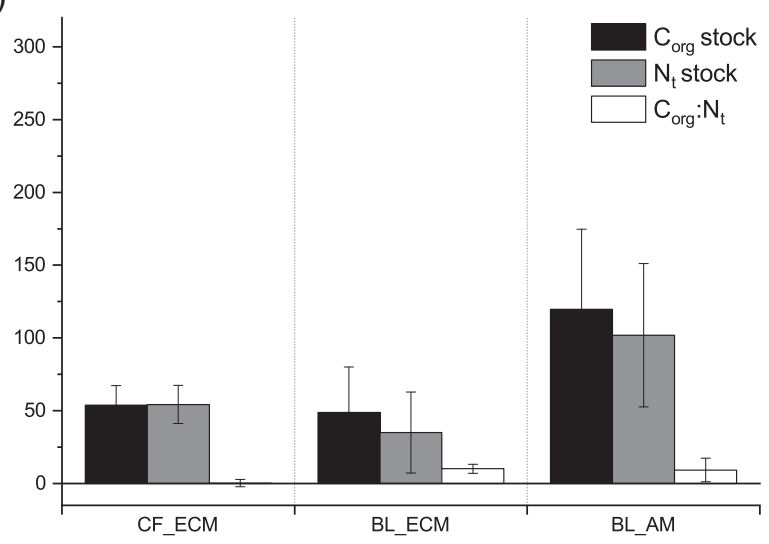

(d)

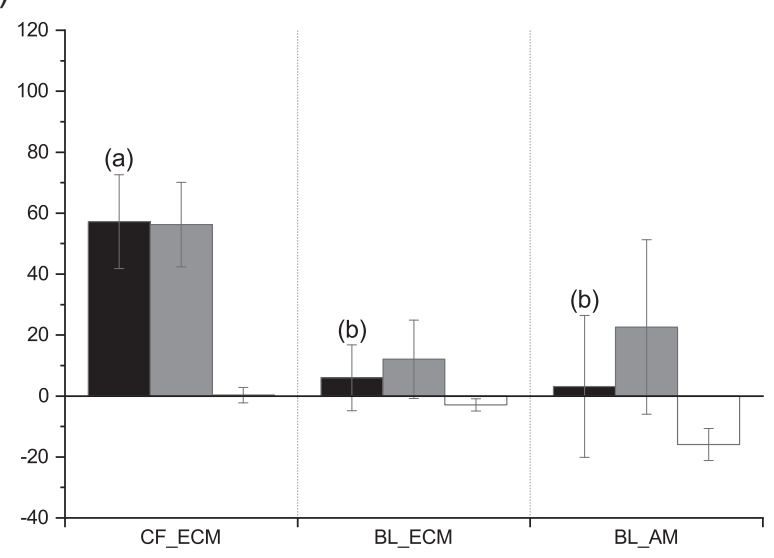

F I G U RE 2 Relative changes in total (c, d) and foliar ( $a, b)$ forest floor $\mathrm{C}_{\text {org }}$ and $\mathrm{N}_{\mathrm{t}}$ stocks as well as $\mathrm{C}_{\text {org }}: \mathrm{N}_{\mathrm{t}}$ ratio from $2004 / 2005$ to $2015 / 2016$. The bars are the mean values of the species (a, c) or species group (b, d) and the error bars correspond to \pm 1 SEM. Different lowercase letters indicate significant differences between species or species groups at $p<0.05$, and if in parentheses, they indicate a trend at $0.05<p<0.1$. AM, arbuscular mycorrhizal; BL, broadleaved; CF, coniferous; ECM, ectomycorrhizal

\section{3 | RESULTS}

\section{1 | Stocks of $C_{\text {org }}$ and $N_{t}$ and $C_{o r g}: N_{t}$ ratio}

TFF and FFF $\mathrm{C}_{\text {org }}$ and $\mathrm{N}_{\mathrm{t}}$ stocks were lowest under ash, maple and lime and highest under spruce (Table 5). The humus forms were eu-mull for maple, ash and lime, dys- mull to moder for beech and oak and mor for spruce (Zanella et al., 2011). The $\mathrm{C}_{\text {org }}: \mathrm{N}_{\mathrm{t}}$ ratio of TFF was not significantly affected by species or species groups, but FFF $\mathrm{C}_{\text {org }}: \mathrm{N}_{\mathrm{t}}$ ratio was smaller in oak than in spruce, beech and lime (Table 5).

In the mineral soil, in $0-5 \mathrm{~cm}$ depth, $\mathrm{C}_{\text {org }}$ stock was greater under spruce than under beech and maple (Table 5), while $\mathrm{N}_{t}$ stock was not affected by species or 
(a)

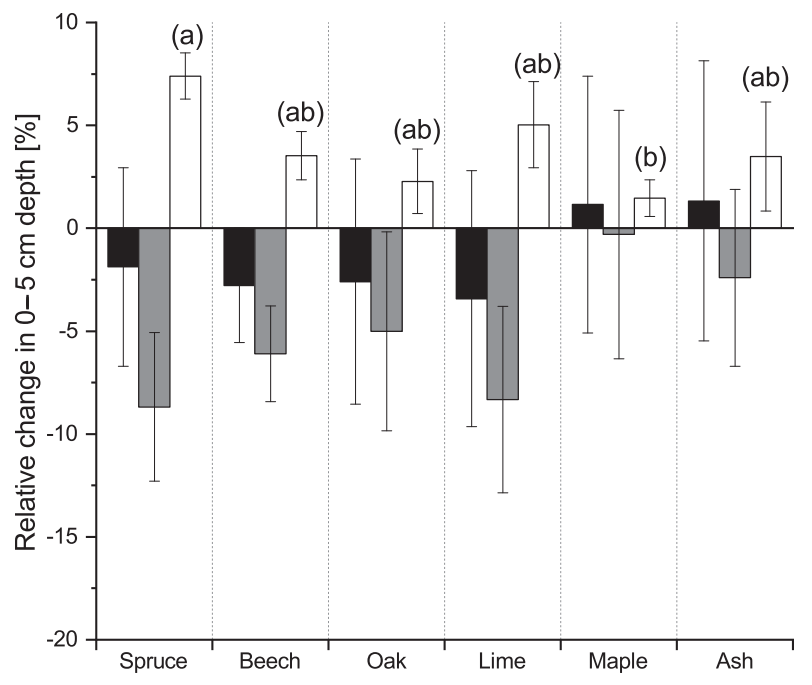

(c)

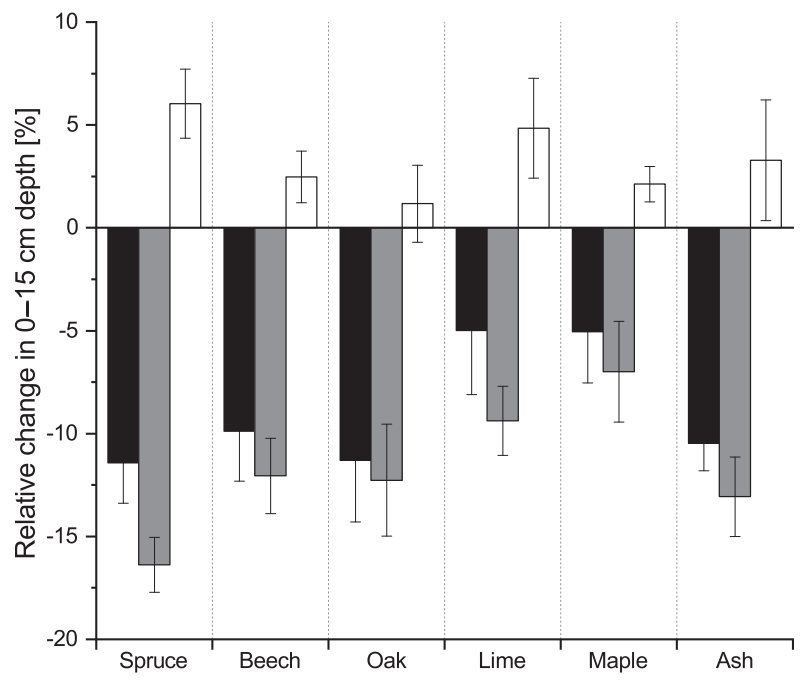

(e)

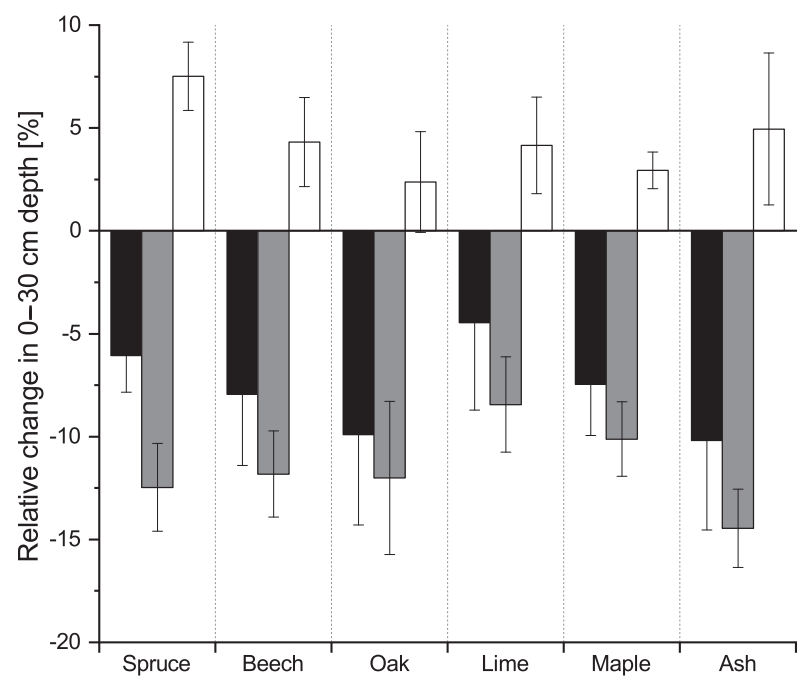

(b) $\mathrm{C}_{\text {org }}$ stock

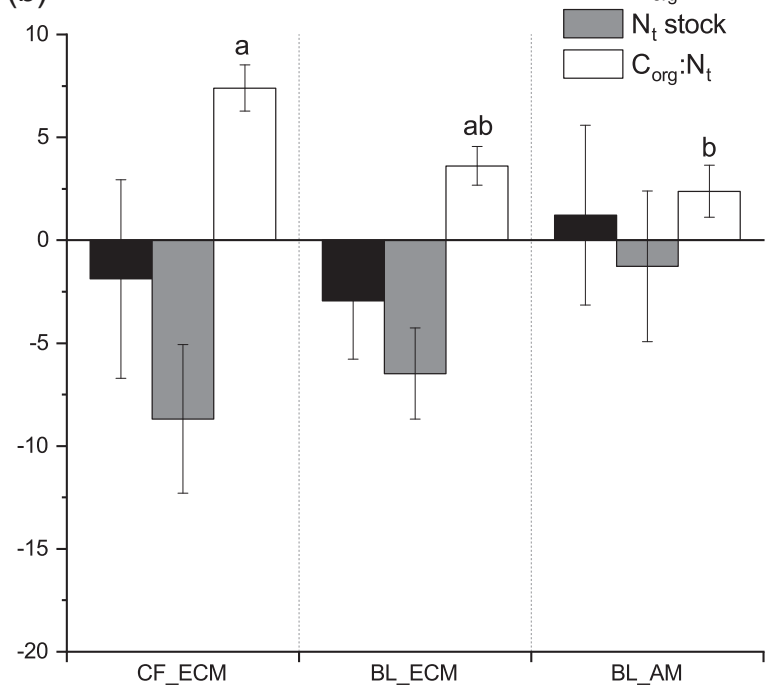

(d)

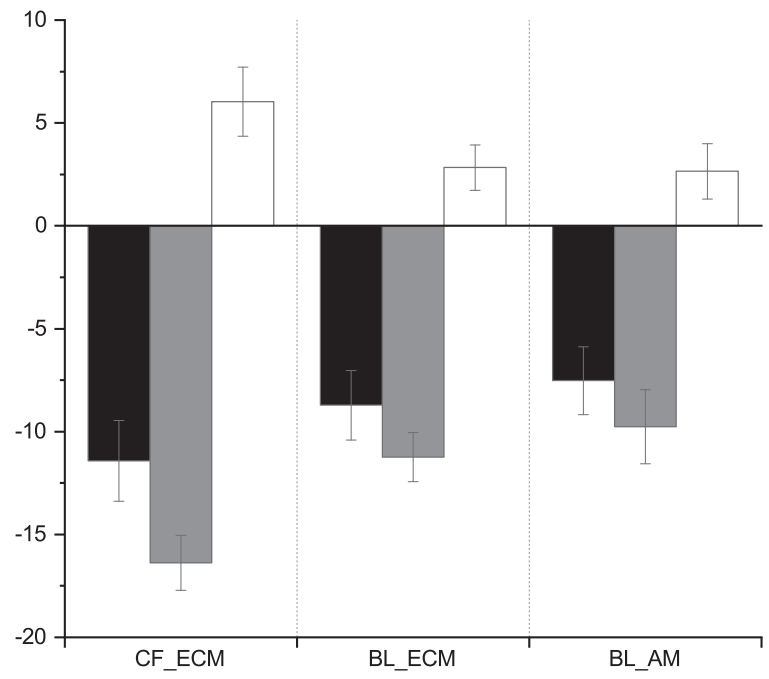

(f)

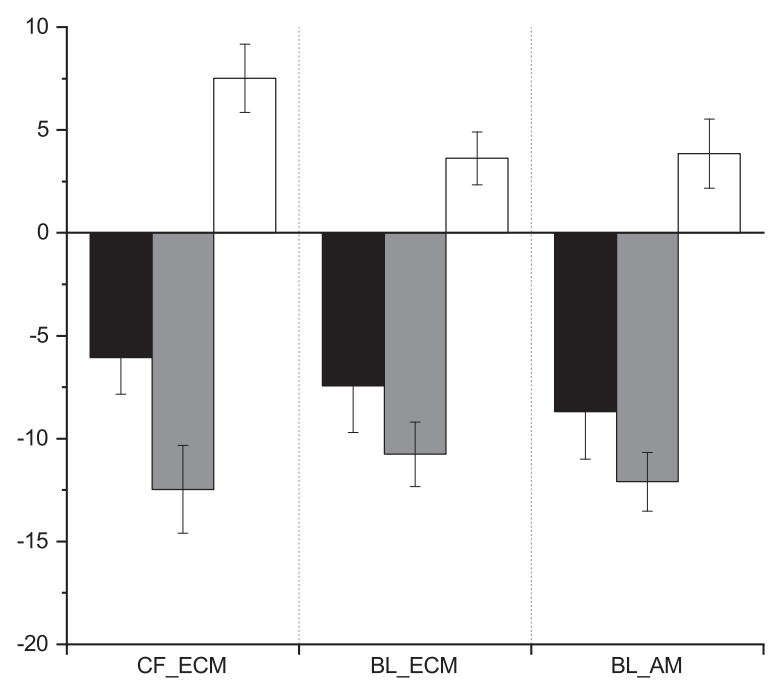

F I G URE 3 Legend on next page. 

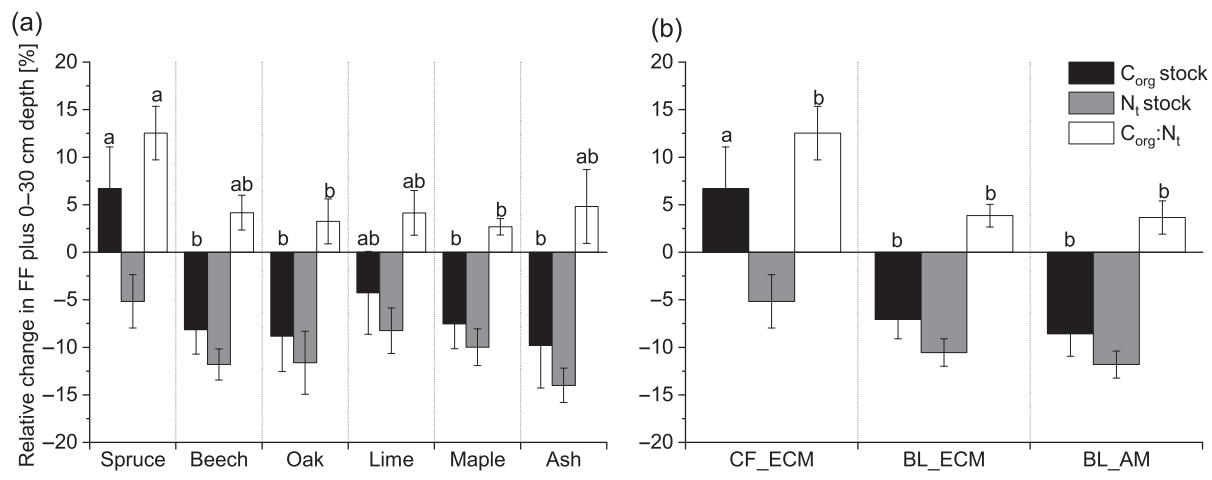

F I G U RE 4 Relative changes in total forest floor (FF) plus mineral topsoil $(0-30 \mathrm{~cm}) \mathrm{C}_{\text {org }}$ and $\mathrm{N}_{\mathrm{t}}$ stocks as well as $\mathrm{C}_{\text {org }}: \mathrm{N}_{\mathrm{t}}$ ratio from $2004 / 2005$ to $2015 / 2016$. The bars are the mean values of the species (a) or species group (b) and the error bars correspond to \pm 1 SEM. Different lowercase letters indicate significant differences between species or species groups at $p<0.05$. AM, arbuscular mycorrhizal; BL, broadleaved; $\mathrm{CF}$, coniferous; ECM, ectomycorrhizal

species groups. No species and species group effects on $\mathrm{C}_{\text {org }}$ stocks were observed for thicker soil layers (0-15 cm and $0-30 \mathrm{~cm}$ ). However, in these layers, $\mathrm{N}_{\mathrm{t}}$ stocks were greater under AM species than under ECM species. Total $\mathrm{C}_{\text {org }}$ stock (TFF $+0-30 \mathrm{~cm}$ of mineral soil) was greater under spruce than under all broadleaved species (Table 5) Total $\mathrm{N}_{\mathrm{t}}$ stock was highest under ash and lowest under beech. The $\mathrm{C}_{\text {org }}: \mathrm{N}_{\mathrm{t}}$ ratio increased in all mineral soil layers in the order BL-AM $<$ BL-ECM $<$ CF-ECM.

\section{2 | Vertical distribution}

In $\mathrm{AM}$ species, $97 \%$ of the $\mathrm{FF}$ and topsoil $(0-30 \mathrm{~cm}) \mathrm{C}_{\mathrm{org}}$ and $99 \%$ of the $\mathrm{N}_{\mathrm{t}}$ stock were stored in the mineral topsoil, and in ECM broadleaved species, the proportions were $94 \%$ for $\mathrm{C}_{\text {org }}$ and $98 \%$ for $\mathrm{N}_{\mathrm{t}}$. In contrast, the proportions in spruce were $\sim 72 \%\left(\mathrm{C}_{\text {org }}\right)$ and $84 \%\left(\mathrm{~N}_{\mathrm{t}}\right)$, respectively. Within the mineral topsoil $(0-30 \mathrm{~cm})$, relatively less $\mathrm{C}_{\text {org }}$ and $\mathrm{N}_{\mathrm{t}}$ was found below $5 \mathrm{~cm}$ under spruce compared to the broadleaved species (Figure 1). The proportion of $\mathrm{C}_{\text {org }}$ and $\mathrm{N}_{\mathrm{t}}$ stored in the $\mathrm{FF}$ increased under spruce since 2004 due to an absolute increase in $\mathrm{FF} \mathrm{C}_{\text {org }}$ and $\mathrm{N}_{\mathrm{t}}$ stocks.

\section{3 | Decadal changes in $\mathrm{C}_{\text {org }}$ and $\mathbf{N}_{\mathbf{t}}$ stocks and their ratios}

In general, $\mathrm{FFF} \mathrm{C}_{\mathrm{org}}$ and $\mathrm{N}_{\mathrm{t}}$ stocks increased from 2004/2005 to 2015/2016 (Figure 2a,b). Relative changes in FFF were most pronounced in BL-AM and on a species level in ash, while relative positive changes in TFF $\mathrm{C}_{\text {org }}$ (and $\mathrm{N}_{\mathrm{t}}$ stocks) were mainly limited to spruce (Figure 2c). TFF $\mathrm{C}_{\text {org }}: \mathrm{N}_{\mathrm{t}}$ ratio decreased significantly under ash from 2004/2005 to 2015/2016 (Figure 2c), while it remained more or less unchanged under spruce, beech and oak. FFF $\mathrm{C}_{\mathrm{org}}: \mathrm{N}_{\mathrm{t}}$ ratio slightly increased under all broadleaved species except ash, but differences between species were not significant (Figure 2a).

Decreases in mineral topsoil $\mathrm{C}_{\text {org }}$ and $\mathrm{N}_{\mathrm{t}}$ stocks were the dominant trend from 2004/2005 to 2015/2016 (Figure 3), and relative losses of $\mathrm{N}_{\mathrm{t}}$ were greater than that of $\mathrm{C}_{\mathrm{org}}$. Although not significant, mean losses of $\mathrm{N}_{t}$ increased in the order BL-AM $<$ BL-ECM $<$ CF-ECM in $0-5 \mathrm{~cm}$ depth, and $\mathrm{C}_{\text {org }}: \mathrm{N}_{\mathrm{t}}$ ratio increased relatively more under CF-ECM than under BL-AM (Figure 3b). This species group ranking disappeared with increasing soil depth (Figure 3d,f).

TFF plus topsoil $\mathrm{C}_{\text {org }}$ stocks increased under spruce from 2004/2005 to 2015/2016 (5.6 $\pm 3.3 \mathrm{Mg} \mathrm{ha}^{-1}$ decade $\left.^{-1}\right)$, but decreased under the broadleaved species $\left(-5.2 \pm 1.2 \mathrm{Mg} \mathrm{ha}^{-1}\right.$ decade $^{-1}$; for relative changes see Figure 4). The $\mathrm{N}_{\mathrm{t}}$ stocks decreased irrespective of species $\left(-0.65 \pm 0.08 \mathrm{Mg} \mathrm{ha}^{-1}\right.$ decade $\left.^{-1}\right)$. However, the relative loss of $\mathrm{N}_{\mathrm{t}}$ from $2004 / 2005$ to $2015 / 2016$ was more pronounced under the broadleaved species. TFF plus topsoil $\mathrm{C}_{\mathrm{org}}: \mathrm{N}_{\mathrm{t}}$ ratio slightly increased (highest in spruce) from $2004 / 2005$ to $2015 / 2016$ (Figure 4).

In the multiple regression analyses, those variables that were affected by tree species were predominantly included in explaining $\mathrm{FF} \mathrm{C}_{\text {org }}$ and $\mathrm{N}_{\mathrm{t}}$ stock changes, while they with

F I G URE 3 Relative changes in $\mathrm{C}_{\text {org }}$ and $\mathrm{N}_{\mathrm{t}}$ stocks as well as the $\mathrm{C}_{\mathrm{org}}: \mathrm{N}_{\mathrm{t}}$ ratio from $2004 / 2005$ to 2015/2016 in three soil increments. The bars are the mean values of the species (a, c, e) or species group (b, d, f) and the error bars correspond to \pm 1 SEM. Different lowercase letters indicate significant differences between species or species groups at $p<0.05$, and if in parentheses, they indicate a trend at $0.05<p<0.1$. AM, arbuscular mycorrhizal; BL, broadleaved; CF, coniferous; ECM, ectomycorrhizal 


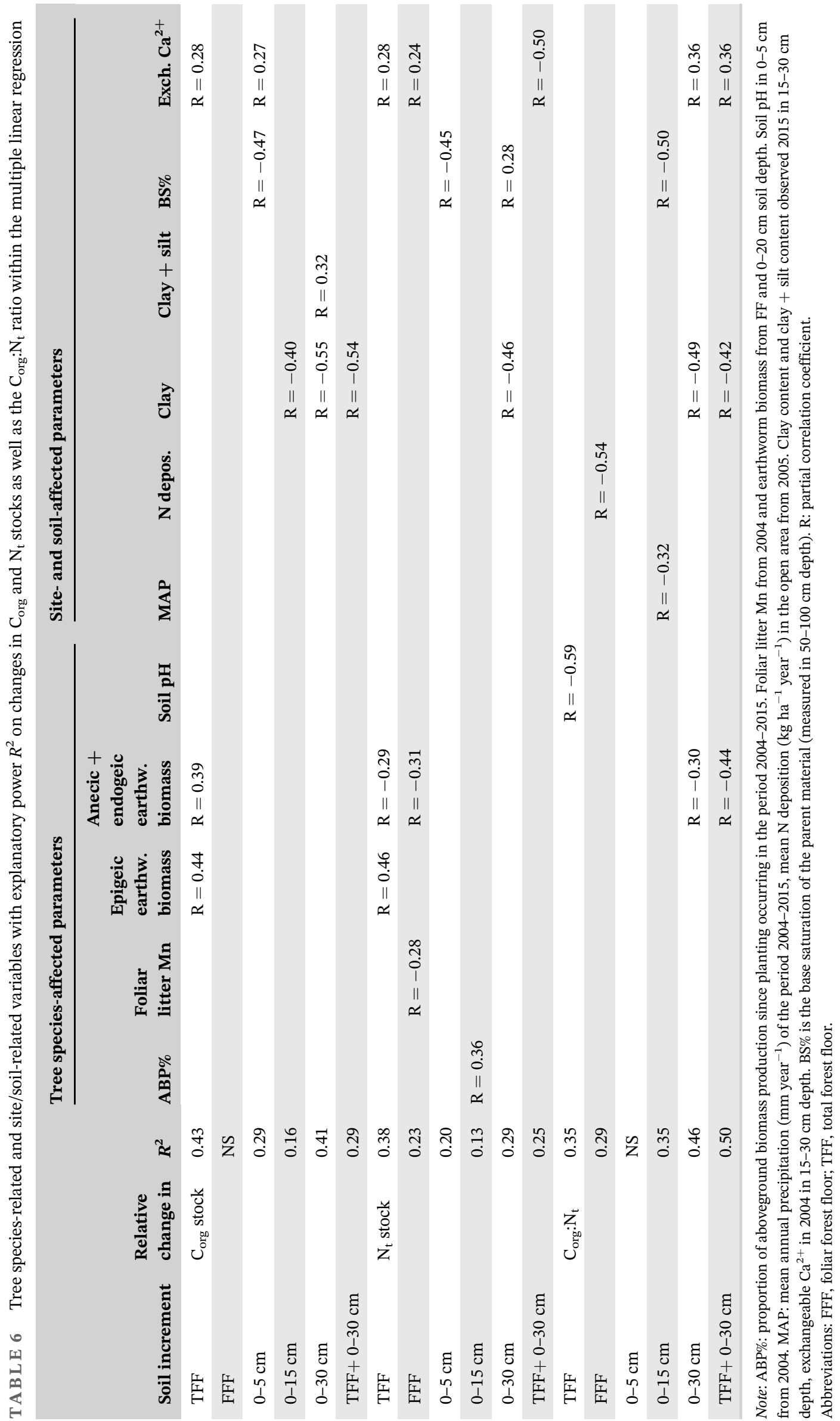


one exception had a negligible role in explaining relative $\mathrm{C}_{\text {org }}$ and $\mathrm{N}_{\mathrm{t}}$ stock changes in the mineral topsoil (Table 6). Earthworms correlated with relative changes in $\mathrm{FF} \mathrm{C}_{\text {org }}$ and $\mathrm{N}_{\mathrm{t}}$ stocks: Losses of $\mathrm{C}_{\text {org }}$ and $\mathrm{N}_{\mathrm{t}}$ were greater under species with a high mass of burrowing earthworms and low biomass of epigeic earthworms. Of the potentially related litter quality and nutrient variables, litter Mn correlated negatively with relative changes in FFF $\mathrm{N}_{\mathrm{t}}$ stocks. In the mineral soil, $A B P \%$ correlated positively with relative changes in $\mathrm{N}_{\mathrm{t}}$ stocks in $0-15 \mathrm{~cm}$, that is, a higher proportion of topsoil $\mathrm{N}_{\mathrm{t}}$ was lost under species with a lower $\mathrm{ABP} \%$.

Individual tree species-affected variables explained relative changes in $\mathrm{C}_{\mathrm{org}}: \mathrm{N}_{\mathrm{t}}$ ratios in a few cases. Relative changes in the TFF $\mathrm{C}_{\text {org }}: \mathrm{N}_{t}$ ratio were smaller under species with a higher $\mathrm{pH}$, while relative changes in mineral topsoil and in TFF plus mineral topsoil were smaller at sites with a greater biomass of burrowing earthworms.

Of the tested soil chemical parameters, base saturation and exchangeable $\mathrm{Ca}^{2+}$ (Table 6) correlated positively with relative changes in $\mathrm{C}_{\text {org }}$ and $\mathrm{N}_{\mathrm{t}}$ stocks in the $\mathrm{FF}$ and the top $5 \mathrm{~cm}$ of mineral soil. In the case of $\mathrm{N}_{\mathrm{t}}$ stock changes, correlations with soil chemical parameters were still relevant in thicker topsoil layers (Table 6). In 0-15 and 0-30 cm, relative changes in topsoil $\mathrm{C}_{\text {org }}$ and $\mathrm{N}_{\mathrm{t}}$ stocks were related to soil physical parameters, indicating higher relative losses at sites with a higher clay content. Relative changes in topsoil $\mathrm{C}_{\mathrm{org}}: \mathrm{N}_{\mathrm{t}}$ ratios were negatively correlated with the clay content. In addition, they were positively correlated with the two soil chemical parameters "exchangeable $\mathrm{Ca}^{2+}$ " and "base saturation".

Among climatic variables, high MAP was associated with smaller changes in $\mathrm{C}_{\text {org }}: \mathrm{N}_{\mathrm{t}}$ (Table 6). $\mathrm{N}$ deposition correlated negatively with relative changes in the $\mathrm{FF} \mathrm{C}_{\text {org }}: \mathrm{N}_{t}$ ratio.

\section{4 | DISCUSSION}

We faced the open question, how temperate FF and topsoil $\mathrm{C}_{\text {org }}$ and $\mathrm{N}_{\mathrm{t}}$ stocks change with time in dependence of tree species, and how tree species effects interact with site properties (Mayer et al., 2020). There is an urgent need for increasing the sink strength for atmospheric $\mathrm{C}$ through targeted selection of tree species in forest management. The present study provides first indications of possible relationships and species effects on decadal $\mathrm{C}_{\text {org }}$ and $\mathrm{N}_{\mathrm{t}}$ stock changes within the FF and mineral topsoil (0$30 \mathrm{~cm}$ ) in a Danish multisite common garden experiment.

\section{1 | Stocks of $\mathrm{C}_{\text {org }}$ and $\mathrm{N}_{\mathrm{t}}$ and their vertical distribution}

Species ranking of $\mathrm{FF}$ and mineral topsoil $\mathrm{C}_{\text {org }}$ and $\mathrm{N}_{\mathrm{t}}$ stocks as well as the vertical distribution was as expected from earlier findings (Achilles et al., 2021; Hagen-Thorn et al., 2004; Langenbruch et al., 2012; Lorenz \& ThieleBruhn, 2019; Oostra et al., 2006; Peng et al., 2020; Vesterdal et al., 2008, 2013). They provide further support that species could be grouped by their effect on $\mathrm{C}_{\text {org }}$ and $\mathrm{N}_{\mathrm{t}}$ dynamics. Ash, lime and maple had leaf litter high in $\mathrm{N}$ and base cations but low in lignin (Vesterdal et al., 2008) contributing to fast decomposition of litterfall and transformation by bacteria-dominated microbial biomass (Hedenec et al., 2020) and translocation by earthworms of $\mathrm{C}_{\text {org }}$ and $\mathrm{N}_{\mathrm{t}}$ to the mineral soil (Schelfhout et al., 2017). Norway spruce acted oppositely: low leaf litter $\mathrm{N}$ and base cation concentrations, high lignin and high soil acidification lead to longer-term storage of $\mathrm{C}_{\text {org }}$ and $\mathrm{N}_{\mathrm{t}}$ within the $\mathrm{FF}$ (mor) due to slow decomposition and mineralisation of litterfall, which partly attributed to low macrofauna abundance and to fungal-dominated microbial community (Hedenec et al., 2020; Schelfhout et al., 2017). Oak and beech are characterised by intermediate leaf litter traits and effects on the $\mathrm{C}_{\text {org }}$ and $\mathrm{N}_{t}$ dynamics.

Compared to European forests, $\mathrm{FF}_{\mathrm{org}}$ stocks under mull-forming species at our sites were rather low (De Vos et al., 2015), which could in part be attributed to the relatively young age of the stands. However, under the mor forming species spruce, the $\mathrm{FF}_{\text {org }}$ stocks fell into the range of earlier published values. Mineral topsoil $(0-30 \mathrm{~cm}) \mathrm{C}_{\text {org }}$ stocks $\left(\sim 53-\sim 64 \mathrm{Mg} \mathrm{ha}^{-1}\right)$ were at the lower end of published values for forested Luvisols in a European context (De Vos et al., 2015). However, topsoil $\mathrm{C}_{\text {org }}$ stocks under beech, oak and spruce in our sites were in the mean range between topsoil $\mathrm{C}_{\text {org }}$ stocks in three 38-year-old even-aged first-generation forest stands that differed strongly in texture and fertility (Ladegaard-Pedersen et al., 2005). The $\mathrm{N}_{\mathrm{t}}$ stocks in the mineral topsoil were within the mean range observed for European forest soils within the ICP Forests programme (Fleck et al., 2016).

\section{2 | $\mathrm{C}_{\text {org }}: \mathrm{N}_{\mathrm{t}}$ ratio}

Differences in the $\mathrm{FF} \mathrm{C}_{\mathrm{org}}: \mathrm{N}_{\mathrm{t}}$ ratio remained uncorrelated with differences in litterfall $\mathrm{N}$ status a decade after the previous sampling (Vesterdal et al., 2008). The $\mathrm{C}_{\text {org }}: \mathrm{N}_{\mathrm{t}}$ ratio variation among tree species was more related to different stages of decomposition of the litter material. Recently fallen litter in the early stages of decomposition is high in $\mathrm{C}_{\text {org }}: \mathrm{N}_{\mathrm{t}}$ ratio, and $\mathrm{N}_{\mathrm{t}}$ will gradually be immobilised in the litter material, thereby reducing the $\mathrm{C}_{\text {org }}: \mathrm{N}_{\mathrm{t}}$ ratio (Berg, 2000). A smaller $\mathrm{C}_{\mathrm{org}}: \mathrm{N}_{\mathrm{t}}$ ratio is characteristic of partly decomposed material, as it can be found in the mor or dys-Mull horizons, while a wider $\mathrm{C}_{\text {org }}: \mathrm{N}_{\mathrm{t}}$ ratio is characteristic of quite undecomposed litter material. The species and species group ranking of 
mineral topsoil $\mathrm{C}_{\mathrm{org}}: \mathrm{N}_{\mathrm{t}}$ ratio was as expected from earlier publications (Peng et al., 2020; Vesterdal et al., 2008).

\section{3 | Decadal changes in $\mathrm{C}_{\text {org }}$ and $\mathrm{N}_{\mathrm{t}}$ stocks and $\mathrm{C}_{\text {org }}: \mathrm{N}_{\mathrm{t}}$ ratio}

\subsection{1 | FF plus topsoil}

The increase of FF plus topsoil $\mathrm{C}_{\text {org }}$ stock under spruce as well as the decrease of it under the broadleaved species was in the range of earlier published individual values for comparable European forest soils (Luvisols) and under even-aged stands (Grüneberg et al., 2014; Jonard et al., 2017). Losses of $\mathrm{N}_{t}$ were at the lower end of earlier published ranges of $\mathrm{N}_{\mathrm{t}}$ changes in FF plus mineral soil after 15 years (Fleck et al., 2019). In their large-scale monitoring study, Fleck et al. (2019) identified that differences in $\mathrm{N}$ deposition, $\mathrm{N}$ emissions, $\mathrm{N}$ leaching and $\mathrm{N}$ uptake by vegetation as well as soil acidification affected forest soil $\mathrm{N}_{\mathrm{t}}$ stock changes across and within forest types and soil types. We expect our decadal losses to be related to a more unfavourable combination of the $\mathrm{N}$ input and output parameters in 2015/2016 compared to 2004/2005.

The strong $\mathrm{C}_{\text {org }}$ increase in the FF under spruce superimposed the $\mathrm{C}_{\text {org }}$ losses in the topsoil, resulting in an overall increase of $\mathrm{C}_{\text {org }}$ stock. In the broadleaved species, FF $\mathrm{C}_{\text {org }}$ and $\mathrm{N}_{\mathrm{t}}$ stocks as well as $\mathrm{C}_{\text {org }}: \mathrm{N}_{\mathrm{t}}$ ratio only played a subordinate to negligible role and we found no evidence for a redistribution of $\mathrm{C}_{\text {org }}$ or $\mathrm{N}_{\mathrm{t}}$ within the soil profile. Therefore, the parameters that explained variation in $\mathrm{C}_{\text {org }}$ and $\mathrm{N}_{\mathrm{t}}$ stocks were very similar to those for the mineral topsoil and will be discussed alongside.

\subsection{2 | Forest floor}

\section{The effect of tree species}

TFF $\mathrm{C}_{\text {org }}$ and $\mathrm{N}_{\mathrm{t}}$ stocks increased strongest under spruce, which was the species with the thickest FF (mor type) that is characterised by slow decomposition and consequently high accumulation of organic matter which is conducive to soil acidification (De Schrijver et al., 2012). Accordingly, Vesterdal et al. (2008) found lowest fractional annual losses of TFF and FFF $\mathrm{C}_{\text {org }}$ and $\mathrm{N}_{\mathrm{t}}$ stocks under Norway spruce, suggesting that it takes longer for this tree species to reach steady-state conditions in the FF than for those with fast decomposing litter (Olson, 1963).

Of the tested tree species-mediated variables, earthworms appeared to have the strongest explanatory strength on relative changes in $\mathrm{FF} \mathrm{C}_{\text {org }}$ and $\mathrm{N}_{\mathrm{t}}$ stocks. With increasing biomass of burrowing earthworms, $\mathrm{C}_{\text {org }}$ and $\mathrm{N}_{\mathrm{t}}$ stocks in the FF increased least or even decreased most from 2004/2005 to 2015/2016. Burrowing earthworm biomass was lowest in spruce and highest in ash, lime and maple (Schelfhout et al., 2017) suggesting highest translocation and/or mineralisation processes of $\mathrm{C}_{\text {org }}$ and $\mathrm{N}_{\mathrm{t}}$ from the FF to deeper soil layers in ash, lime and maple and lowest in spruce (Angst, Mueller, Prater, et al., 2019). Epigeic earthworms live in the litter layer or FF. It is, therefore, not unexpected that we observed a positive correlation between these litter-dwelling earthworms and the relative changes in $\mathrm{FF} \mathrm{C}_{\text {org }}$ and $\mathrm{N}_{\mathrm{t}}$ stocks.

Foliar litter quality and nutrient variables appeared to play a minor role. However, tree species low in litter $\mathrm{Mn}$ (e.g., ash) had larger FFF $\mathrm{N}_{\mathrm{t}}$ increases. Foliar litter $\mathrm{N}$ and Mn were negatively correlated (not shown). We therefore expect that we observed simply an accumulation of FF N and that the foliar litter $\mathrm{N}$ was the causal driver for this change.

Similarly, we expect the correlation of the soil $\mathrm{pH}$ with relative changes in the TFF $\mathrm{C}_{\text {org }}: \mathrm{N}_{t}$ ratio to be of random nature, as in the mull-forming species where non-foliar FF was the dominant part of TFF at sampling time, the TFF $\mathrm{C}_{\text {org }}: \mathrm{N}_{\mathrm{t}}$ ratio highly depended on the ratio between twigs and fruits (Hansen et al., 2009) and we expect these fractions to be highly temporally variable.

\section{The effect of soil and site variables}

In the FF, the impact of soil- and site-related variables on relative changes of $\mathrm{C}_{\text {org }}$ and $\mathrm{N}_{\mathrm{t}}$ stocks (exchangeable $\mathrm{Ca}^{2+}$ ) as well as $\mathrm{C}_{\text {org }}: \mathrm{N}_{\mathrm{t}}$ ratio ( $\mathrm{N}$ deposition) was subordinate compared to species-related variables and their direction within regression analyses was opposite to what we would have expected from common understanding. There is little evidence of mechanisms to support their explanatory value and we expect them to be mostly of random nature.

\subsection{3 | Mineral topsoil}

The multiple common garden sites were established on former arable land or beech forest in 1973 (1961 for Kragelund), that is, $\sim 30$ years prior to first and $\sim 40$ years prior to second sampling. One decade is a significant time interval since establishment of the tree species plots and we expect the sites had not yet reached new steady-state levels. Mayer et al. (2020) reviewed that steady-state conditions may not happen within 100 years after afforestation. Furthermore, clear-cut harvesting, as has happened at four of the six sites prior to establishment of the common garden experiment, is well-known to result in significant losses of FF and at some cases also of mineral soil 
$\mathrm{C}_{\text {org }}$ stocks. Chronosequence studies suggested that 1-5 decades after the harvest, the stocks started to recover (Mayer et al., 2020). Considering this, we would have expected small, but significant increases in $\mathrm{C}_{\text {org }}$ and $\mathrm{N}_{\mathrm{t}}$ stocks in some tree species that we suggest also to happen for a few more decades until the sites had reached new steady-state conditions. Furthermore, we expect that the tree species-related differences in $\mathrm{C}_{\text {org }}$ and $\mathrm{N}_{\mathrm{t}}$ stocks would have intensified from $2004 / 2005$ to $2015 / 2016$. In contrast, we observed relative losses in topsoil $\mathrm{C}_{\text {org }}$ and even stronger losses in $\mathrm{N}_{\mathrm{t}}$ stocks between 2004/2005 and 2015/2016 irrespective of tree species. Soil- and siterelated variables were found to have a much stronger explanatory power on decadal changes in $\mathrm{C}_{\text {org }}$ and $\mathrm{N}_{t}$ stocks as well as the $\mathrm{C}_{\text {org }}: \mathrm{N}_{\mathrm{t}}$ ratio than species-related parameters, which was in agreement with a study by Brock et al. (2019) on a comparison of deciduous stands versus $\sim 50$-year-old monoculture spruce plantations that were converted from the adjacent deciduous stands.

\section{The effect of tree species}

Among the species-related variables, earthworms had the strongest impact on relative changes in topsoil $\mathrm{C}_{\text {org }}: \mathrm{N}_{t}$ ratios. The ranking in relative increases in $\mathrm{C}_{\mathrm{org}}: \mathrm{N}_{\mathrm{t}}$ ratios in 0-5 cm depth from BL-AM species over BL-ECM species to spruce was related to differences in burrowing earthworm biomass. It hints towards a positive feedback of earthworms on translocation and microbial immobilisation of $\mathrm{N}$ to support a more long-lasting sink from the litter to the soil and on an increased capacity for microbial biomass (with a smaller $\mathrm{C}_{\mathrm{org}}: \mathrm{N}_{\mathrm{t}}$ ratio than bulk soil $\mathrm{C}_{\text {org }}: \mathrm{N}_{\mathrm{t}}$ ratio) (Groffman et al., 2015). From this, we expect a greater $\mathrm{N}$ mineralisation and immobilisation in earthworm-rich soils, such as under BL-AM, than in earthworm poor soils, such as under spruce. Supportingly, Lin et al. (2017) found greater mineral $\mathrm{N}$ and $\mathrm{N}$ turnover in soils under AM species with a mineral $\mathrm{N}$ economy compared with ECM species with an organic $\mathrm{N}$ economy.

Results indicated that in $0-15 \mathrm{~cm}$ depth, less $\mathrm{N}$ was lost from the soil under species with high $\mathrm{ABP} \%$. We assume this to relate to temporary processes and to indicate different forest development status among the species. Nord-Larsen and Pretzsch (2017) found that mean ABP peaked after a few decades in spruce species, while beech had not yet reached its maximum ABP after almost 50 years. Litterfall rate was reported to relate positively with ABP (Hansen et al., 2009, Matala et al., 2008). The $\mathrm{N}_{\mathrm{t}}$ losses could be attributed to species-specific variations in litterfall $\mathrm{N}$ inputs with time (Portillo-Estrada et al., 2013) as a consequence of species-specific variation in biomass production. A slight decline in litterfall inputs could be a consequence of a rather low $\mathrm{ABP} \%$ as found for spruce. In contrast, a rather high $\mathrm{ABP} \%$ (as in beech) might indicate more litterfall inputs. From this, we expect a greater loss of accumulated but unstabilised topsoil $\mathrm{N}_{\mathrm{t}}$ under spruce compared to beech.

\section{The effect of soil and site variables}

The clay content was associated significantly with relative changes in $\mathrm{C}_{\text {org }}$ stocks (and partly $\mathrm{N}_{\mathrm{t}}$ stocks), and its impact increased with increasing depth. Results indicated stronger losses of $\mathrm{C}_{\text {org }}$ (and $\mathrm{N}_{\mathrm{t}}$ stocks) at sites with a greater clay content. In accordance, Grüneberg et al. (2019) found in their meta-study on $C_{\text {org }}$ stock changes in German forests a negative impact of the clay content. Also, Verstraeten et al. (2018) found soils with a greater clay content were in general positively related with endogeic and epigeic earthworm biomass, but these soils were also more sensitive to the impacts of acidification caused by conversion of broadleaved forests to conifer plantation. Clay-rich soils have a greater cation exchange capacity and, therefore, a greater capacity to accumulate exchangeable aluminium which in turn negatively affects soil communities such as burrowing earthworms. This could cause translocation of $\mathrm{C}_{\mathrm{org}}$ and $\mathrm{N}_{\mathrm{t}}$ from the FF to the mineral soil and its cycling to slow down. Angst, Mueller, Eissenstat, et al. (2019) and Hobbie et al. (2007) found a positive correlation between clay content and $\mathrm{CO}_{2}$-respiration from the soil. We speculate that the observed negative correlation hints towards temporal accumulation and mineralisation of labile $\mathrm{C}_{\text {org }}$, which could partly be related to the fact that $\mathrm{BS} \%$ was greater in soils with greater clay content. Results indicated faster mineralisation processes in soils with a greater BS\%. This could be due to a positive impact of the base saturation and $\mathrm{pH}$ on microbial biomass (Angst, Mueller, Eissenstat, et al., 2019) and activity (Hedenec et al., 2020). Clay content explained a greater portion of variability in relative changes in $\mathrm{C}_{\text {org }}$ stocks than in $\mathrm{N}_{t}$ stocks. This resulted also in a negative correlation of the clay content with relative changes in the $\mathrm{C}_{\text {org }}: \mathrm{N}_{\mathrm{t}}$ ratio.

Results indicated that at sites with a high concentration of clay plus silt, a smaller proportion of $\mathrm{C}_{\text {org }}$ was lost. This might indicate a stabilisation process due to, for example, adsorption to mineral surface (Jandl et al., 2007; Six et al., 2002), but as this correlation was opposite to the observed stronger impact of the clay content, it might as well have been a random correlation.

The positive correlation of exchangeable $\mathrm{Ca}^{2+}$ with relative changes in topsoil $\mathrm{C}_{\text {org }}$ stocks could hint towards stabilisation through the formation of bridges between mineral surfaces and soil organic matter (Rasmussen et al., 2018), however, this process is more typical for less acidic soils $(\mathrm{pH}>5.5)$ (Angst, Mueller, Eissenstat, et al., 2019). Therefore, we expect it rather to be a 
random correlation or a proxy for other soil characteristics beyond the focus of our study. In contrast, relative changes in $\mathrm{N}_{\mathrm{t}}$ stocks in TFF $+0-30 \mathrm{~cm}$ soil depth were negatively correlated with exchangeable $\mathrm{Ca}^{2+}$. Exchangeable $\mathrm{Ca}^{2+}$ positively correlated with the biomass of burrowing earthworms and with earthworm abundance (Schelfhout et al., 2017). Thus, we speculate that labile, that is, accumulated but not yet stabilised, $\mathrm{N}_{\mathrm{t}}$ was lost from the soil.

At our sites, the small variation in climatic variables only marginally related to relative changes in $\mathrm{C}_{\text {org }}: \mathrm{N}_{\mathrm{t}}$ ratios. At sites with a greater MAP, the $\mathrm{C}_{\text {org }}: \mathrm{N}_{t}$ ratio decreased strongly in the $0-15 \mathrm{~cm}$ soil depth. This might be related to a faster leaching of dissolved $\mathrm{N}$ from the $\mathrm{FF}$ to the mineral soil at sites with a greater MAP (Christiansen et al., 2010). Our results do not allow any conclusion on long-term effects of this correlation and future research is necessary.

\section{4 | Temporal dynamics or long-term changes?}

We found first indications that $\mathrm{N}_{\mathrm{t}}$ long-term stabilisation occurred through the positive feedback of burrowing earthworms on translocation and microbial immobilisation of $\mathrm{N}$ (Groffman et al., 2015). We suggest that $\mathrm{N}_{\mathrm{t}}$ stabilisation within the topsoil was greater under species associated with AM than under spruce. However, the overall observed topsoil $\mathrm{C}_{\text {org }}$ and $\mathrm{N}_{\mathrm{t}}$ losses from 2004/2005 to 2015/2016 were related to decomposition patterns of labile $\mathrm{C}_{\text {org }}$. The ratio of labile $\mathrm{C}_{\text {org }}$ accumulation to its mineralisation varies interannually due to differences in MAT and MAP affecting $\mathrm{ABP}$ and litter input on the one hand and mineralisation rate of labile $\mathrm{C}_{\mathrm{org}}$ on the other hand (Luan et al., 2014; Teramoto et al., 2016). Because of these prominent temporal dynamics, we conclude that one decade was not long enough to detect increases of $\mathrm{C}_{\text {org }}$ and $\mathrm{N}_{\mathrm{t}}$ within the mineral soil when looking at bulk stocks. Future research should concentrate on changes of $\mathrm{C}_{\text {org }}$ and $\mathrm{N}_{\mathrm{t}}$ in different fractions within the soil (density, aggregate and particle size).

Mayer et al. (2020) stated that thinning might temporarily reduce soil $\mathrm{C}_{\text {org }}$ stocks within the first few years. The sites under study had been thinned every 4 years since canopy closure, including the year prior to samplings, that is, in 2004 and in 2015, and in addition in 2009. Thinning intensity differed slightly between sites and species and it tended to increase over the years (Jørgensen, personal communication). This could in addition have contributed to the observed negative changes in $\mathrm{C}_{\text {org }}$ and $\mathrm{N}_{\mathrm{t}}$ stocks from 2004/2005 to 2015/2016.

\section{CONCLUSION}

Norway spruce separated from the broadleaved species with greater $\mathrm{C}_{\text {org }}$ and $\mathrm{N}_{\mathrm{t}}$ stocks and a different vertical distribution from FF to topsoil. Spruce formed a thick FF (mor) that further increased from 2004 to 2015. It tended to have lowest $\mathrm{N}_{\mathrm{t}}$ stocks and the widest $\mathrm{C}_{\text {org }}: \mathrm{N}_{\mathrm{t}}$ ratio in the mineral topsoil. It is therefore inferred to have a slow $\mathrm{C}_{\text {org }}$ and $\mathrm{N}_{\mathrm{t}}$ cycling. Among the broadleaved species, ash and maple distinguished clearly from spruce. The humus form was eu-mull, which inferred a fast $\mathrm{C}_{\text {org }}$ and $\mathrm{N}_{\mathrm{t}}$ cycling. In the mineral soil, the mycorrhizal association seemed to be a relevant grouping trait, as lime was more associated with beech and oak (BL-ECM) than with ash and maple (BL-AM), which tended to have highest topsoil $\mathrm{N}_{\mathrm{t}}$ stocks and the narrowest topsoil $\mathrm{C}_{\text {org }}: \mathrm{N}_{\mathrm{t}}$ ratio.

Contrary to our hypotheses, losses of topsoil $\mathrm{C}_{\text {org }}$ and $\mathrm{N}_{\mathrm{t}}$ stocks were a dominant trend from 2004/2005 to $2015 / 2016$ irrespective of tree species or species group. We expect these losses to be of temporal nature, for example, due to interannual variability in accumulation and mineralisation dynamics. We found one first indication for a species effect on soil $\mathrm{N}_{\mathrm{t}}$ sequestration through earthworms that were strongly dependent on the overstory tree species. We speculate that-as hypothesisedmore $\mathrm{N}_{\mathrm{t}}$ was stored under BL-AM species than under spruce in the past decade. As expected, FF $\mathrm{C}_{\text {org }}$ and $\mathrm{N}_{\mathrm{t}}$ stocks increased strongest under spruce. Contrary to our expectations, topsoil $\mathrm{C}_{\text {org }}$ stock changes were predominantly correlated with site and soil-related parameters. We expect that species effects did occur but were too small to be detectable within the large pool of bulk soil $\mathrm{C}_{\text {org }}$ after one decade. Future studies should concentrate on different fractions of soil organic matter that were related to different degrees of organic matter persistence, for example, density fractions or separation by aggregate size and stability.

\section{ACKNOWLEDGEMENTS}

We thank the DFG for funding, the foresters and landowners for giving permission to conduct the research in the respective forest stands, J.L. Bak for providing data on $\mathrm{N}$ deposition and B. B. Jørgensen for providing data and information on biomass production and thinning.

Open access funding enabled and organized by Projekt DEAL.

\section{AUTHOR CONTRIBUTIONS}

Christina Steffens: Conceptualization (lead); formal analysis (lead); funding acquisition (lead); investigation (lead); methodology (lead); visualization (lead); writing - 
original draft (lead); writing - review and editing (lead). Christian Beer: Validation (equal); writing - review and editing (supporting). Stephanie Schelfhout: Investigation (supporting); writing - review and editing (supporting). An De Schrijver: Investigation (supporting). Eva-Maria Pfeiffer: Conceptualization (supporting); resources (equal); supervision (equal); writing - review and editing (supporting). Lars Vesterdal: Conceptualization (supporting); methodology (supporting); resources (equal); supervision (equal); validation (equal); writing - review and editing (supporting).

\section{DATA AVAILABILITY STATEMENT}

The data that support the findings of this study are available from the corresponding author upon reasonable request.

\section{ORCID}

\section{Christina Steffens (10) https://orcid.org/0000-0002-5170-}

031X

\section{REFERENCES}

Achilles, F., Tischer, A., Bernhardt-Romermann, M., Heinze, M., Reinhardt, F., Makeschin, F., \& Michalzik, B. (2021). European beech leads to more bioactive humus forms but stronger mineral soil acidification as Norway spruce and Scots pine - Results of a repeated site assessment after 63 and 82 years of forest conversion in Central Germany. Forest Ecology and Management, 483, 118769. https://doi.org/10.1016/j.foreco.2020.118769

Angst, G., Mueller, C. W., Prater, I., Angst, S., Frouz, J., Jílková, V., Peterse, F., \& Nierop, K. G. J. (2019). Earthworms act as biochemical reactors to convert labile plant compounds into stabilized soil microbial necromass. Communications Biology, 2, 441. https://doi.org/10.1038/s42003-019-0684-z

Angst, G., Mueller, K. E., Eissenstat, D. M., Trumbore, S., Freeman, K. H., Hobbie, S. E., Chorover, J., Oleksyn, J., Reich, P. B., \& Mueller, C. W. (2019). Soil organic carbon stability in forests: Distinct effects of tree species identity and traits. Global Change Biology, 25(4), 1529-1546. https://doi.org/10. $1111 /$ gcb. 14548

Bak, J., Løfstrøm, P., \& Damgaard, C. F. (2018). Vurdering af virkninger på natur og miljø af forskellige modeller for cendret regulering af ammoniakemission. Videnskabelig rapport, 275, Aarhus Universitet, DCE - Nationalt Center for Miljø og Energi.

Barnett, A. G., van der Pols, J. C., \& Dobson, A. J. (2005). Regression to the mean: What it is and how to deal with it. International Journal of Epidemiology, 34(1), 215-220. https://doi.org/ 10.1093/ije/dyh299

Bates, D., Machler, M., Bolker, B. M., \& Walker, S. C. (2015). Fitting linear mixed-effects models using lme4. Journal of Statistical Software, 67(1), 1-48. https://doi.org/10.18637/jss.v067.i01

Berg, B. (2000). Litter decomposition and organic matter turnover in northern forest soils. Forest Ecology and Management, 133(1-2), 13-22. https://doi.org/10.1016/S0378-1127(99)00294-7

Boca, A., Van Miegroet, H., \& Gruselle, M. C. (2014). Forest overstory effect on soil organic carbon storage: A meta-analysis. Soil
Science Society of America Journal, 78, S35-S47. https://doi.org/ 10.2136/sssaj2013.08.0332nafsc

Brock, O., Kooijman, A., Nierop, K. G. J., Muys, B., Vancampenhout, K., \& Jansen, B. (2019). Disentangling the effects of parent material and litter input chemistry on molecular soil organic matter composition in converted forests in Western Europe. Organic Geochemistry, 134, 66-76. https://doi. org/10.1016/j.orggeochem.2019.05.006

Christiansen, J. R., Vesterdal, L., Callesen, I., Elberling, B., Schmidt, I. K., \& Gundersen, P. (2010). Role of six European tree species and land-use legacy for nitrogen and water budgets in forests. Global Change Biology, 16(8), 2224-2240. https://doi.org/10.1111/j.1365-2486.2009.02076.x

Cotrufo, M. F., Wallenstein, M. D., Boot, C. M., Denef, K., \& Paul, E. (2013). The Microbial Efficiency-Matrix Stabilization (MEMS) framework integrates plant litter decomposition with soil organic matter stabilization: Do labile plant inputs form stable soil organic matter? Global Change Biology, 19(4), 988995. https://doi.org/10.1111/gcb.12113

Curry, J. P., \& Schmidt, O. (2007). The feeding ecology of earthworms - A review. Pedobiologia, 50, 463-477. https://doi.org/ 10.1016/j.pedobi.2006.09.001

De Vos, B., Cools, N., Ilvesniemi, H., Vesterdal, L., Vanguelova, E., \& Camicelli, S. (2015). Benchmark values for forest soil carbon stocks in Europe: Results from a large scale forest soil survey. Geoderma, 251, 33-46. https://doi.org/10. 1016/j.geoderma.2015.03.008

Ellermann, T., Bossi, R., Nygaard, J., Christensen, J., Løfstrøm, P., Monies, C., Grundahl, L., Geels, C., Nielsen, I. E., \& Bech Poulsen, M. (2018). Atmosforisk Deposition 2016.

Fleck, S., Cools, N., De Vos, B., Meesenburg, H., \& Fischer, R. (2016). The level II aggregated forest soil condition database links soil physicochemical and hydraulic properties with longterm observations of forest condition in Europe. Annals of Forest Science, 73(4), 945-957. https://doi.org/10.1007/s13595-0160571-4

Fleck, S., Eickenscheidt, N., Ahrends, B., Evers, B., Gruneberg, E., Ziche, D., Hohle, J., Schmitz, A., Weis, W., Schmidt-Walter, P., Andreae, H., \& Wellbrock, N. (2019) Nitrogen Status and Dynamics in German Forest Soils. In N. Wellbrock \& A. Bolte (Eds.), Status and Dynamics of Forests in Germany. Ecological Studies (Analysis and Synthesis) (Vol. 237, pp. 123-166). Cham: Springer. https://doi.org/10.1007/978-3-030-15734-0_5

Goodale, C. L., Apps, M. J., Birdsey, R. A., Field, C. B., Heath, L. S., Houghton, R. A., Jenkins, J. C., Kohlmaier, G. H., Kurz, W., Liu, S. R., Nabuurs, G. J., Nilsson, S., \& Shvidenko, A. Z. (2002). Forest carbon sinks in the northern hemisphere. Ecological Applications, 12(3), 891-899. https://doi.org/10.1890/10510761(2002)012[0891:Fcsitn]2.0.Co;2

Groffman, P. M., Fahey, T. J., Fisk, M. C., Yavitt, J. B., Sherman, R. E., Bohlen, P. J., \& Maerz, J. C. (2015). Earthworms increase soil microbial biomass carrying capacity and nitrogen retention in northern hardwood forests. Soil Biology \& Biochemistry, 87, 51-58. https://doi.org/10.1016/j.soilbio.2015.03.025

Grüneberg, E., Schöning, I., Riek, W., Ziche, D., \& Evers, J. (2019). Carbon Stocks and Carbon Stock Changes in German Forest Soils. In N. B. Wellbrock \& A. Bolte (Eds.), Status and Dynamics of Forests in Germany. Ecological Studies (Analysis and Synthesis) (Vol. 237, pp. 167-198). Cham: Springer. https://doi.org/ 10.1007/978-3-030-15734-0_6 
Grüneberg, E., Ziche, D., \& Wellbrock, N. (2014). Organic carbon stocks and sequestration rates of forest soils in Germany. Global Change Biology, 20(8), 2644-2662. https://doi.org/10.1111/gcb. 12558

Gundersen, P., Berg, B., Currie, W. S., Dise, N. B., Emmet, B. A., Gauci, V., Holmberg, M., Kjonaas, O. J., Mol-Dijkstra, J., van der Salm, C., Schmidt, I. K., Tietema, A., Wessel, W. W., Vestgarden, L. S., Akselsson, C., De Vries, W., Forsius, M., Kros, H., Matzner, E., ... Wright, R. F. (2006). Carbon-nitrogen interactions in forest ecosystems: final report. Center for Skov, Landskab og Planlægning/Københavns Universitet.

Hagen-Thorn, A., Callesen, I., Armolaitis, K., \& Nihlgard, B. (2004). The impact of six European tree species on the chemistry of mineral topsoil in forest plantations on former agricultural land. Forest Ecology and Management, 195(3), 373-384. https:// doi.org/10.1016/j.foreco.2004.02.036

Hansen, K., Vesterdal, L., Schmidt, I. K., Gundersen, P., Sevel, L., Bastrup-Birk, A., Pedersen, L. B., \& Bille-Hansen, J. (2009). Litterfall and nutrient return in five tree species in a common garden experiment. Forest Ecology and Management, 257(10), 2133-2144. https://doi.org/10.1016/j.foreco.2009.02.021

Harley, J. L., \& Harley, E. L. (1987). A checklist of mycorrhiza in the British Flora - Addenda, errata and index. New Phytologist, 107(4), 741-749. https://doi.org/10.1111/j.1469-8137.1987. tb00912.x

Hedenec, P., Nilsson, L. O., Zheng, H. F., Gundersen, P., Schmidt, I. K., Rousk, J., \& Vesterdal, L. (2020). Mycorrhizal association of common European tree species shapes biomass and metabolic activity of bacterial and fungal communities in soil. Soil Biology \& Biochemistry, 149, 107933. https://doi.org/ 10.1016/j.soilbio.2020.107933

Hobbie, S. E., Ogdahl, M., Chorover, J., Chadwick, O. A., Oleksyn, J., Zytkowiak, R., \& Reich, P. B. (2007). Tree species effects on soil organic matter dynamics: The role of soil cation composition. Ecosystems, 10(6), 999-1018. https://doi.org/10. 1007/s10021-007-9073-4

Hobbie, S. E., Reich, P. B., Oleksyn, J., Ogdahl, M., Zytkowiak, R., Hale, C., \& Karolewski, P. (2006). Tree species effects on decomposition and forest floor dynamics in a common garden. Ecology, 87(9), 2288-2297. https://doi.org/10.1890/0012-9658 (2006)87[2288:TSEODA]2.0.CO;2

IUSS Working Group WRB. (2015). World Reference Base for Soil Resources 2014, update 2015. International soil classification system for naming soils and creating legends for soil maps. World Soil Resources Reports, 106, Rome: FAO.

Jandl, R., Lindner, M., Vesterdal, L., Bauwens, B., Baritz, R., Hagedorn, F., Johnson, D. W., Minkkinen, K., \& Byrne, K. A. (2007). How strongly can forest management influence soil carbon sequestration? Geoderma, 137(3-4), 253-268. https://doi. org/10.1016/j.geoderma.2006.09.003

John Fox, S. W. (2019). An R companion to applied regression (3rd ed.). Sage.

Jonard, M., Nicolas, M., Coomes, D. A., Caignet, I., Saenger, A., \& Ponette, Q. (2017). Forest soils in France are sequestering substantial amounts of carbon. Science of the Total Environment, 574, 616-628. https://doi.org/10.1016/j.scitotenv.2016.09.028

Kögel-Knabner, I., Ekschmitt, K., Flessa, H., Guggenberger, G., Matzner, E., Marschner, B., \& von Luetzow, M. (2008). An integrative approach of organic matter stabilization in temperate soils: Linking chemistry, physics, and biology. Journal of Plant Nutrition and Soil Science, 171(1), 5-13. https://doi.org/10. 1002/jpln.200700215

Kuznetsova, A., Brockhoff, P. B., \& Christensen, R. H. B. (2017). lmerTest package: Tests in linear mixed effects models. Journal of Statistical Software, 82(13), 1-26. https://doi.org/10.18637/ jss.v082.i13

Ladegaard-Pedersen, P., Elberling, B., \& Vesterdal, L. (2005). Soil carbon stocks, mineralization rates, and $\mathrm{CO}_{2}$ effluxes under 10 tree species on contrasting soil types. Canadian Journal of Forest Research, 35(6), 1277-1284. https://doi.org/10.1139/ X05-045

Lal, R. (2005). Forest soils and carbon sequestration. Forest Ecology and Management, 220(1-3), 242-258. https://doi.org/10.1016/j. foreco.2005.08.015

Langenbruch, C., Helfrich, M., \& Flessa, H. (2012). Effects of beech (Fagus sylvatica), ash (Fraxinus excelsior) and lime (Tilia spec.) on soil chemical properties in a mixed deciduous forest. Plant and Soil, 352(1-2), 389-403. https://doi.org/10.1007/s11104-011-1004-7

Lawrence, G. B., Fernandez, I. J., Hazlett, P. W., Bailey, S. W., Ross, D. S., Villars, T. R., Quintana, A., Ouimet, R., McHale, M. R., Johnson, C. E., Briggs, R. D., Colter, R. A., Siemion, J., Bartlett, O. L., Vargas, O., Antidormi, M. R., \& Koppers, M. M. (2016). Methods of soil resampling to monitor changes in the chemical concentrations of forest soils. Journal of Visualized Experiments, 117, e54815. https://doi.org/10.3791/ 54815

Lawrence, G. B., Fernandez, I. J., Richter, D. D., Ross, D. S., Hazlett, P. W., Bailey, S. W., Ouimet, R., Warby, R. A. F., Johnson, A. H., Lin, H., Kaste, J. M., Lapenis, A. G., \& Sullivan, T. J. (2013). Measuring environmental change in forest ecosystems by repeated soil sampling: A north American perspective. Journal of Environmental Quality, 42(3), 623-639. https://doi.org/10.2134/jeq2012.0378

Lee, J., Hopmans, J. W., Rolston, D. E., Baer, S. G., \& Six, J. (2009). Determining soil carbon stock changes: Simple bulk density corrections fail. Agriculture Ecosystems \& Environment, 134(34), 251-256. https://doi.org/10.1016/j.agee.2009.07.006

Lenth, R. V. (2016). Least-squares means: The R package lsmeans. Journal of Statistical Software, 69(1), 1-33. https://doi.org/10. 18637/jss.v069.i01

Li, T. J., Ren, B. W., Wang, D. H., \& Liu, G. B. (2015). Spatial variation in the storages and age-related dynamics of Forest carbon sequestration in different climate zones-evidence from black locust plantations on the loess plateau of China. PLoS One, 10(3), e0121862. https://doi.org/10.1371/journal.pone.0121862

Lin, G. G., McCormack, M. L., Ma, C. E., \& Guo, D. L. (2017). Similar below-ground carbon cycling dynamics but contrasting modes of nitrogen cycling between arbuscular mycorrhizal and ectomycorrhizal forests. New Phytologist, 213(3), 1440-1451. https://doi.org/10.1111/nph.14206

Lorenz, M., \& Thiele-Bruhn, S. (2019). Tree species affect soil organic matter stocks and stoichiometry in interaction with soil microbiota. Geoderma, 353, 35-46. https://doi.org/10.1016/j. geoderma.2019.06.021

Luan, J. W., Liu, S. R., Chang, S. X., Wang, J. X., Zhu, X. L., Liu, K., \& Wu, J. H. (2014). Different effects of warming and cooling on the decomposition of soil organic matter in warmtemperate oak forests: A reciprocal translocation experiment. 
Biogeochemistry, 121(3), 551-564. https://doi.org/10.1007/s10533014-0022-y

Matala, J., Kellomäki, S., \& Nuutinen, T. (2008). Litterfall in relation to volume growth of trees: Analysis based on literature. Scandinavian Journal of Forest Research, 23(3), 194-202. https://doi.org/10.1080/02827580802036176

Mayer, M., Prescott, C. E., Abaker, W. E. A., Augusto, L., Cecillon, L., Ferreira, G. W. D., James, J., Jandl, R., Katzensteiner, K., Laclau, J. P., Laganiere, J., Nouvellon, Y., Pare, D., Stanturf, J. A., Vanguelova, E. I., \& Vesterdal, L. (2020). Tamm review: Influence of forest management activities on soil organic carbon stocks: A knowledge synthesis. Forest Ecology and Management, 466, 118127. https://doi.org/10.1016/j.foreco.2020.118127

Mellilo, J. M., Aber, J. D., \& Muratore, J. F. (1982). Nitrogen and lignin control of hardwood leaf litter decomposition dynamics. Ecology, 63(3), 621-626. https://doi.org/10.2307/1936780

Nord-Larsen, T., \& Pretzsch, H. (2017). Biomass production dynamics for common forest tree species in Denmark - Evaluation of a common garden experiment after 50 yrs of measurements. Forest Ecology and Management, 400, 645-654. https://doi.org/10. 1016/j.foreco.2017.06.035

Olson, J. S. (1963). Energy storage and the balance of producers and decomposers in ecological systems. Ecology, 44(2), 322-331.

Oostra, S., Majdi, H., \& Olsson, M. (2006). Impact of tree species on soil carbon stocks and soil acidity in southern Sweden. Scandinavian Journal of Forest Research, 21(5), 364-371. https://doi. org/10.1080/02827580600950172

Pan, Y. D., Birdsey, R. A., Fang, J. Y., Houghton, R., Kauppi, P. E., Kurz, W. A., Phillips, O. L., Shvidenko, A., Lewis, S. L., Canadell, J. G., Ciais, P., Jackson, R. B., Pacala, S. W., McGuire, A. D., Piao, S. L., Rautiainen, A., Sitch, S., \& Hayes, D. (2011). A large and persistent carbon sink in the world's forests. Science, 333(6045), 988-993. https://doi.org/10. 1126/science.1201609

Peng, Y., Schmidt, I. K., Zheng, H. F., Hedenec, P., Bachega, L. R., Yue, K., Wu, F. Z., \& Vesterdal, L. (2020). Tree species effects on topsoil carbon stock and concentration are mediated by tree species type, mycorrhizal association, and $\mathrm{N}$-fixing ability at the global scale. Forest Ecology and Management, 478, 118510 https://doi.org/10.1016/j.foreco.2020.118510

Portillo-Estrada, M., Korhonen Janne, F. J., Pihlatie, M., Pumpanen, J., Frumau Arnoud, K. F., Morillas, L., Tosens, T., \& Niinemets, Ü. (2013). Inter- and intra-annual variations in canopy fine litterfall and carbon and nitrogen inputs to the forest floor in two European coniferous forests. Annals of Forest Science, 70(4), 367-379. https://doi.org/10.1007/s13595-0130273-0

Rasmussen, C., Heckman, K., Wieder, W. R., Keiluweit, M., Lawrence, C. R., Berhe, A. A., Blankinship, J. C., Crow, S. E., Druhan, J. L., Hicks Pries, C. E., Marin-Spiotta, E., Plante, A. F., Schädel, C., Schimel, J. P., Sierra, C. A., Thompson, A., \& Wagai, R. (2018). Beyond clay: Towards an improved set of variables for predicting soil organic matter content. Biogeochemistry, 137, 297-306. https://doi.org/10.1007/s10533-018-0424-3

Rodeghiero, M., Vesterdal, L., Marcolla, B., Vescovo, L., Aertsen, W., Martinez, C., Di Cosmo, L., Gasparini, P., \& Gianelie, D. (2018). Soil nitrogen explanatory factors across a range of forest ecosystems and climatic conditions in Italy.
Forest Ecology and Management, 408, 25-35. https://doi.org/10. 1016/j.foreco.2017.10.039

Schelfhout, S., Mertens, J., Verheyen, K., Vesterdal, L., Baeten, L., Muys, B., \& De Schrijver, A. (2017). Tree species identity shapes earthworm communities (vol 8, 85, 2017). Forests, 8(10), 366. https://doi.org/10.3390/f8100366

De Schrijver, A., Frenne, P., Staelens, J., Verstraeten, G., Muys, B., Vesterdal, L., Wuyts, K., Nevel, L., Schelfhout, S., Neve, S., \& Verheyen, K. (2012). Tree species traits cause divergence in soil acidification during four decades of postagricultural forest development. Global Change Biology, 18(3), 1127-1140. https:// doi.org/10.1111/j.1365-2486.2011.02572.x

Schrumpf, M., Schulze, E. D., Kaiser, K., \& Schumacher, J. (2011). How accurately can soil organic carbon stocks and stock changes be quantified by soil inventories? Biogeosciences, $8(5)$, 1193-1212. https://doi.org/10.5194/bg-8-1193-2011

Schulze, E. D. (2000). The carbon and nitrogen cycle of Forest ecosystems. In J. Schumacher (Ed.), Carbon and nitrogen cycling in European forest ecosystems (Vol. 142, pp. 3-13). Springer.

Shao, P. S., Liang, C., Lynch, L., Xie, H. T., \& Bao, X. L. (2019). Reforestation accelerates soil organic carbon accumulation: Evidence from microbial biomarkers. Soil Biology \& Biochemistry, 131, 182-190. https://doi.org/10.1016/j.soilbio.2019.01.012

Six, J., Conant, R. T., Paul, E. A., \& Paustian, K. (2002). Stabilization mechanisms of soil organic matter: Implications for C-saturation of soils. Plant and Soil, 241(2), 155-176. https:// doi.org/10.1023/A:1016125726789

Spencer Graves, H.-P. P., Selzer, L., \& Dorai-Raj, S. (2019). Visualizations of paired comparisons. In (version 0.1-8) [package].

Teramoto, M., Liang, N. S., Takagi, M., Zeng, J. Y., \& Grace, J. (2016). Sustained acceleration of soil carbon decomposition observed in a 6-year warming experiment in a warm-temperate forest in southern Japan. Scientific Reports, 6, 35563. https:// doi.org/10.1038/srep35563

Verstraeten, G., Vancampenhout, K., Desie, E., De Schrijver, A., Hlava, J., Schelfhout, S., Verheyen, K., \& Muys, B. (2018). Tree species effects are amplified by clay content in acidic soils. Soil Biology \& Biochemistry, 121, 43-49. https://doi.org/10.1016/j. soilbio.2018.02.021

Vesterdal, L., Clarke, N., Sigurdsson, B. D., \& Gundersen, P. (2013). Do tree species influence soil carbon stocks in temperate and boreal forests? Forest Ecology and Management, 309, 4-18.

Vesterdal, L., Elberling, B., Christiansen, J. R., Callesen, I., \& Schmidt, I. K. (2012). Soil respiration and rates of soil carbon turnover differ among six common European tree species. Forest Ecology and Management, 264, 185-196. https://doi.org/10. 1016/j.foreco.2011.10.009

Vesterdal, L., Schmidt, I. K., Callesen, I., Nilsson, L. O., \& Gundersen, P. (2008). Carbon and nitrogen in forest floor and mineral soil under six common European tree species. Forest Ecology and Management, 255(1), 35-48. https://doi.org/10. 1016/j.foreco.2007.08.015

Wendt, J. W., \& Hauser, S. (2013). An equivalent soil mass procedure for monitoring soil organic carbon in multiple soil layers. European Journal of Soil Science, 64(1), 58-65. https://doi.org/ 10.1111/ejss. 12002

Zanella, A., Jabiol, B., Ponge, J. F., Sartori, G., De Waal, R., Van Delft, B., Graefe, U., Cools, N., Katzensteiner, K., Hager, H., \& Englisch, M. (2011). A European morpho-functional 
classification of humus forms. Geoderma, 164(3-4), 138-145. https://doi.org/10.1016/j.geoderma.2011.05.016

Zhang, K., Dang, H., Zhang, Q., \& Cheng, X. (2015). Soil carbon dynamics following land-use change varied with temperature and precipitation gradients: Evidence from stable isotopes. Global Change Biology, 21, 2762-2772. https://doi.org/10.1111/gcb.12886

\section{SUPPORTING INFORMATION}

Additional supporting information may be found in the online version of the article at the publisher's website.
How to cite this article: Steffens, C., Beer, C., Schelfhout, S., De Schrijver, A., Pfeiffer, E.-M., \& Vesterdal, L. (2021). Do tree species affect decadal changes in soil organic carbon and total nitrogen stocks in Danish common garden experiments? European Journal of Soil Science, 1-20. https://doi. org/10.1111/ejss.13206 